\title{
STUDIES ON OLIVIDAE
}

by Eveline and Ernesto Marcus

(with 11 plates)

\section{CONTENTS}

1. Introduction $\ldots \ldots \ldots \ldots \ldots \ldots \ldots \ldots \ldots \ldots \ldots \ldots \ldots \ldots \ldots$

2. Classification of the material ................. 101

3. Notes on living snails .................... 103

4. External features ........................ 107

5. Mantle appendages $\ldots \ldots \ldots \ldots \ldots \ldots \ldots \ldots \ldots \ldots \ldots \ldots$

6. Pedal glands

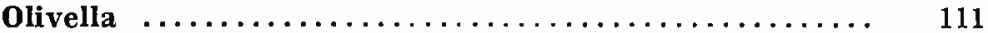

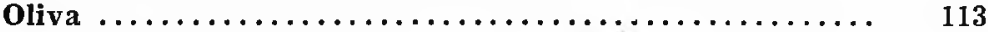

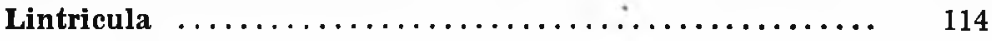

7. Central nervous system

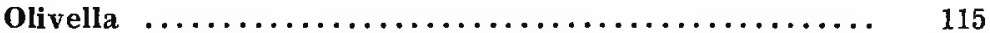

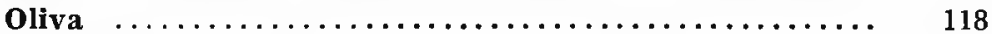

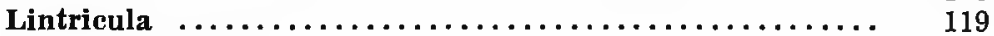

8. Alimentary tract

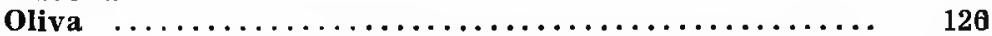

Lintricula and olivancillaria ................. 128

9. Reproductive organs

Olivella, male ............................ 130

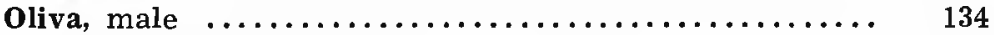

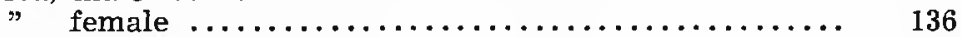

Lintricula, male ....................... 139

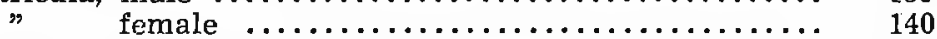

Olivancillaria, female .................... 143

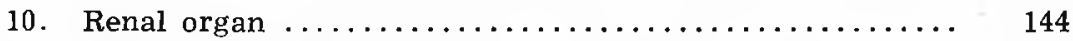

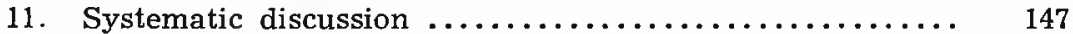

12. Summary $\ldots \ldots \ldots \ldots \ldots \ldots \ldots \ldots \ldots \ldots \ldots \ldots \ldots \ldots \ldots \ldots$

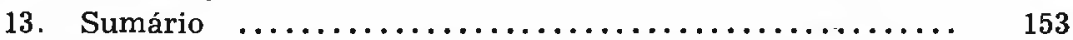

14. References .......................... 156

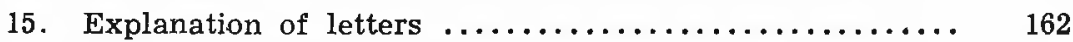

16. Plates ............................... 165 


\section{INTRODUCTION}

We use the name Stenoglossa in the sense of Risbec's "StéInoglosses vrais" (1955, p. 76). Hence the Toxoglossa (Terebracea and Mitracea) are held apart, though the nervous system of the Mitracea is similar to that of the Stenoglossa (Ibid., p. 73). The Stenoglossa comprise a number of families related with one another, whose grouping in three "stirpes" (superfamilies) is somewhat artificial. This is shown by the terms of the diagnoses for these "stirpes" (Thiele 1931, p. 287, 301, 330). Nevertheless we continue to use the names Muricacea, Buccinacea, and Volutacea, because they are still useful in the present state of our knowledge. One of our purposes is to examine the position of the Olividae, a family of the Volutacea, in the Stenoglossa, principally by comparison with Muricacea and Buccinacea.

As the Volutacea are scarcely represented in European seas, they are little known, e. g. not treated in the modern comparative studies of Graham (1941; 1949), Fretter (1941), and Johansson (1957). Anatomical observations regarding the Volutacea were published by Woodward (1900), Bergh (1901), Pace (1902), and Eales (1923, p. 33-38). Also the classical works of Bouvier (1887), Perrier (1889), and Bernard (1890) deal with many anatomical details of several Volutacea. Their most important results are recorded by Simroth (1896-1907), and their informations concerning the olivids, as well as those of further contemporary authors were cited by Haller (1905) and Küttler (1913). Both studied Oliva peruviana, and specially Küttler's work was useful for us. Recently Risbec $(1955$, p. 50, 62) described the oesophageal glands and the central nervous system of Oliva erythrostoma.

Of the two other genera we studied, Olivella and Olivancillaria, the first lives nearer to the centres of malacological studies. Therefore certain aspects of its life were already recorded (P. Fischer 1881; Crosse \& Fischer 1882) and some of the organs were figured (Dall 1889, t. 34, f. 1). The radular characters, also known of Olivancillaria, were combined with 
the differences of the sheils in the recent systematic monograph of Olivella (Olsson 1956).

The following study contains anatomical and other observations of Olivella verreauxii (Ducros 1857), Oliva sayana $\mathrm{Ra}$ venel 1834, Olivancillaria (Lintricula) auricularia (Lamarck 1810), and Olivancillaria (Olivancillaria) brasiliensis (Chemnitz 1788).

\section{CLASSIFICATION OF THE MATERIAL}

We established the name of our operculate Olivella on the basis of Olsson's monograph (1956). The key (p. 166-168) of shell characters leads to the subgenera with a separate pillar structure (CCCc), among which Dactylidiella (p. 187) was forgotten. The latter contains only one large recent species with a range from the Gulf of California to northern Peru. Mansfieldella (p. 194) is known by a single species from the Pliocene of Florida. In Macgintiella the inner side of the pillar wall is deeply excavated, and the rhachidian tooth of the radula ( $f$. 19 on p. 162) differs considerably from our material. The two cemaining subgenera with a separate pillar structure are Dac(ylidia (p. 183) and Niteoliva (p. 189). Their types have often been confused (p. 191), but the rhachidian teeth (f. 17, 15) are wite different. The present species agrees with Niteoliva. The two Atlantic species of this subgenus are minuta (Link 1807) and verreauxii (Ducros 1857). Fortunately Olsson reprinted (p. 191) the original description of Ducros whose "Revue critiquu du genre Oliva" is not at our disposal. This description separates minuta and verreauxii univocally. Also Reeve's pictures (1850) which we compared in accordance with Olsson's synorıymy, lead to the name verreauxii for our species.

Lange (1949, p. 101) and Olsson (1956, p. 219) indicate only Bahia as Brazilian locality for $\mathbf{O}$. (N.) verreauxii. The whitened shell of this species shows a lirated inner side of the outer lip in Olssons photograph (t. 9, f. 3). In our materis' internal lirations of the outer lip were found only in 3 shells out of 50 examined for this structure. It is an inconstant character as in 
o. (N.) minuta and O. (N.) peterseni. In O. (N.) morrisoni it is absent.

We have compared our material with the descriptions of all species of Olivella listed from Brazilian waters by Lange (1949), Gofferje (1950) and Souza Lopes \& Alvarenga (1955, p. 176) and considered their synonymy (E. A. Smith 1890, p. 487; Olsson 1956) . Lange's "Olivella mutica petiolita Dall, 1889" (1949, p. 101) could not be located in any of Dall's numerous papers we consulted. However we did not have Dall's preliminary catalogue (Bull. U. S. Nat. Mus. 37) at our disposal. We only found "Olivella mutica Say var. petiolita Ducl." used by Ihering (1897, p. 170) for a species from the Island of São Sebastião. The name cannot be maintained, because $\mathbf{O}$. mutica Say 1822 is the type of the operculate subgenus Dactylidia, while O. petiolita Duclos 1835 belongs to the subgenus Olivella without operculum.

The name of our Oliva is sufficiently justified by the agreement of our material with the descriptions and figures of Reeve (1850, t. 11, f. 18), Weinkauff (1878, p. 64, t. 15, f. 1-8) and Abbott (1955, p. 245, t. 12, fig. a). The bright yellow form citrina Johnson $(1911$, p. 123$)$ is not represented in our material. As Dr. R. Tucker Abbott kindly informed by letter of April 21, 1958, $\mathbf{O}$. citrina is a colour form, not a subspecies, and thus it is not correct to write $\mathbf{O}$. sayana sayana. The species occurs from North Carolina (Johnson 1934, p. 133) southward to Sta. Catharina (Gofferjé 1950, p. 247). E. A. Smith (1890, p. 487) reported it from Fernando Noronha; Lange (1949, p. 101) from the Island of São Sebastião. The catalogue of Lange mentions O. reticularis $\mathrm{Lm}$., which Ihering (1897, p. 170) listed from São Sebastião, only from Bahia.

The exact form of the name, the author's name, and year can only be settled for one of our two species of the genus Olivancillaria d'Orbigny $(1841$, p. 420$)$ with the bibliography at our disposal. This is the type of the subgenus Lintricula $H$. \& A. Adams (1853, p. 141, cited from Neave, Nomenclator Zoologicus), O. (L.) auricularia (Lamarck 1810, p. 323). The other species, the type of the genus Olivancillaria, has, as far as we 
can see, to be called O. (O.) brasiliensis (Chemnitz 1788; paper not seen). Our names agree with those indicated by Lange de Morretes (1949, p. 100). We have compared our material with d'Orbigny (1. c.), Reeve $(1850$, t. 18, f. 13 a-b, f. 39) and Weinkauff $(1878$, p. 19.50,52). The geographic distribution of both species extends Irom Rio de Janeiro to the Gulf of San Matias, Lat. $42^{\circ}$ S. (Carcelles 1944, p. 259). Carcelles found O. (L.) auricularia among mytilids, probably where the rocks were surrounded by sand.

In the following we refer to Lintricula and Olivancillaria with their subgeneric names only.

\section{NOTES ON LIVING SNAILS}

Of Olivella verreauxii 21 males and 73 females were found in December 1954, West of Ubatuba at the Enseada. At the same place Mr. Caio Del Rio Garcia collected some 50 specimens in August 1958 with the same sex-ratio. In November 1958 we found hundreds of these snails at the Enseada and neighbouring beaches (Praia do Lázaro. Praia Domingos Dias). The shells are about $11 \mathrm{~mm}$. long and $5 \mathrm{~mm}$. broad. The localities correspond to Bales' (1946, p. 47) and Olsson's descriptions of the places where they found Oliva and Olivella. The Enseada is a typical "Feinsandstrand" of the littoral of São Paulo, as Gerlach (1957, p. 416-419) described it. At high tide it receives the surf of the open ocean, though weakened by a broad gradually sloping shore of fine and clean sand. At a normal low tide $(0,3$ at $\varepsilon, 10$ a. m.) on December 9,1954 the snails crawled immediately beneath the surface of the sand exposed to air but still wet without emerging from the sand. The snails are found on the broader end of their trail (Fig. 1). They were active near the surface for about half an hour from $8,30-9 \mathrm{~h}$. then all disappeared long before the tide re-covered the beach. Like $\mathbf{O}$. tehuelchana observed by d'Orbigny (1841, p. 418) and other species (Olsson 1956, p. 161) also $\mathbf{0}$. verreauxii swims by means of its wing-like metapodial flans. 
The stomach contains principally Bivalvia (Donax hanleyanus) and besides Foraminifera, Cnpepoda, Amphipoda, and Scaphopoda. As Dall (1889, p. 134) noted, clams one third as long as the snail's shell may be swallowed whole. When we offered crushed larger Donax to the snails in a dish, they tore particles of them, till the shells were emptied, leaving back only the occlusor muscles. This observation corresponds to Ankel's statement (1938, p. 276) that firm muscular elements cannot be torn off from a loose shell, if it is not held fast with the foot. Skeletons of diatoms occur in the faeces of the snail, probably as contents of the guts of their prey.

We collected 26 living specimens of Oliva sayana in November 1957 in the upper littoral of the Island of São Sebastião, in a sheltered sandy bay near Ilhabela. The topography of the shore at this place differs from Bales' and Olsson's above cited ecological indications. The narrow strand shelves rather steeply to the bottom of the bay. This consists of middle fine, slightly muddy sand near the shore and seawards of mud. At normal low tides the trails of the olives forming two parallel ridges could be seen about $50 \mathrm{~cm}$. below the surface, provided that the water was calm. The few empty shells of $\mathbf{O}$. sayana washed ashore at Ilhabela are all corroded. This shows that the snails go deeper when the water becomes agitated and are not as easily dislodged by the waves as Bulla striata, in any case not in the rarely rough sea in the canal of São Sebastião.

Our material of Oliva sayana was composed of 21 males and 5 females, the former with an average length of the shells of $49,9 \mathrm{~mm}$., the latter with one of $44,5 \mathrm{~mm}$. Also Küttler (1913) had only 3 females of Oliva peruviana and evidently many more males. In our material the variation of the proportion between greatest diameter and length ranges from $1: 2,36$ to $1: 2,17$ without correlation with size or sexes. Our largest empty shell was $73 \mathrm{~mm}$. long and $30 \mathrm{~mm}$. in greatest diameter. Ten half-grown, 22-38 mm. long and only slightly worn shells were found on the surf-beaten sandy beach of the Ilha Comprida near Cananéia in July 1958. 
The contents of the stomachs in our snails were small crustaceans and juice. Meat juice as food of Oliva was already supposed by Weinkauff $(1878$, p. 5). He cites Quoy \& Gaimard's observation that on Mauritius Oliva is baited with meat. Generally the species of Oliva are called scavengers (Graham 1955, p. 151). The anatomy of the nerve ring of Oliva sayana impedes an Oliva really to swallow an Olivella, as Olsson (1956, p. 164) indicates. Probably it grasps its prey with the foot, scrapes particles off with the radula and sucks them in, as Lintricula auricularia does.

Our material of 72 living Lintricula auricularia (Fig. 3) was brought together with the efficient help of Dr. Claudio Gilberto Froehlich and Mr. Caio Del Rio Garcia. Their observations are included in our report. The snail is common on gradually sloping shores with fine an clean sand along the entire coast of the State of São Paulo, from Ubatuba in the Northeast to the Ilha Comprida near Cananéia in the Southwest. Near Ubatuba, on the Praia de Itaguá, the animal is so frequent that it is collected and boiled with the daily rice; the people call it "vitela" (veal), perhaps due to its white flesh, or "vaquinha" (little cow). The shells are sold by the litre for ornamental purposes. The shells of our collection were $8-56 \mathrm{~mm}$. long, the largest empty conch was $60 \mathrm{~mm}$., smaller than Gofferjé's (1950, p. 246) biggest specimen of $68 \mathrm{~mm}$. Both sexes were present in nearly equal numbers in July and August 1958, and without noticeable difference of size.

The adult snails were found at the water-line in fine sand and in shallow water in loose shelly sand, as well as rather high over the low tide-line in rather dry sand. It seems that the snails prefer somewhat loose sand, as occurs just below the high water-line. When caught, the snails expel water from their mantle cavity. Some half-grown animals were dredged in a depth of 4-5 m., together with many dead shells of bivalves. Several times the snails were frequent in the sand in the neighbourhood of the mouths of rivulets. Perhaps the unflow of fresh-water plankton which dies in the sea and sinks down favours the bivalves upon which the snails feed. Among 
the bivalves Donax hanleyanus constitutes the common food of L. auricularia on the coast of São Paulo. The snails shove the sand aside and leave a trail. Sometimes the shell stands partly out from the sand. Anaesthetized animals become well stretched.

When specimens were brought together with Donax, they grasped the clams, as Hirsch (1915, p. 382) described it for Natica. The snail drags one or two clams about in the concavity of its metapodium. A dish with snails was put on a tripod for observing the act of ingestion with help of a mirror placed under the dish. In order to intensify the chemical stimulus for the snails exposed to artificial conditions out of the sand, we offered them clams with cracked valves. Immediately the snails everted their proboscis towards the prey in front of thern and tore off particles of the flesh with their radula (Fig. 4-7). If the clam is seized with the metapodium, the head is curved downwards and the proboscis everted along the median furrow of the propodium to reach the food on the shortest possible way.

$\mathrm{Wh}_{\mathrm{i}}$ en the proboscis is everted (Fig. 8) the red pharyngeal region and the white salivary glands shine through the proboscidean wall, and brownish food particles are pumped upwards through the white oesophagus by peristalsis. The brilliant radula comes out at the orifice of the proboscis and tears small pieces of the mantle from the valve of Donax. During feeding the pharynx moves intensely and changes its position within the proboscis turning to the dorsal or ventral side. Feeding went on for at least 2 hours. The snails succeeded to tear particles from Donax lying loosely in the dish (Fig. 3), also without fixing them with their foot. In a bowl with a layer of sand so high that the Lintricula were covered, they fed regularly on large living Donax as under natural conditions and cleaned the shells completely with their proboscis.

When the foot encloses prey with its sharp posterior margin it appears, in dorsal view, rounded and thick, as if it was swollen, though it is really rather flat. This aspect together with the backward bent proboscis might explain Olsson's des- 
cription (1956, p. 164) of an Oliva undatella swallowing an Olivella whole and swelling into a large, rounded, ball-like mass. Olsson thought that the mouth of olivids opens on the ventral surface of the metapodium near its forward margin (p. 161).

Of Olivancillaria brasiliensis (Fig. 2) we found only 3 middle-sized individuals alive with $34-43 \mathrm{~mm}$. long shells, 1 male and 2 females, near the water-line of the Ilha Comprida, though empty conchs (19-62 mm.) were much more numerous there than those of $\mathbf{L}$. auricularia. The shells of brasiliensis are much more solid, but this difference hardly explains satisfactorily why they were far more frequent than those of auricularia. We still ignore the regular habitat of $\mathbf{O}$. brasiliensis. According to d'Orbigny (1841, p. 420) the species lives in depths of 4-5 m. (Rio de Janeiro), but Gofferjé (1950, p. 246) found it half burried in the sand and following the tide-line (coast of Paraná) in the same manner as auricularia. Our biggest empty shells surpass Gofferjé's of $55 \mathrm{~mm}$.

\section{EXTERNAL FEATURES}

In Olivella verreauxii (Fig. 10-12) the zigzagged lines of the shell vary very much, $5-12$ being visible from one side on the body whorl. Exceptionally these lines are wanting, and the entire shell is uniformly yellow. The brown pigment of the lines belongs to one of the layers under the uppermost one. It evidently lies in an organic substance between the calcareous layers, because it remains coherent, forming ribbons when the shell is decalcified. The same applies to the brown pigment of Oliva sayana. The shells of L. auricularia found on the Ilha Comprida had a bluish hue, while those from a beach West of Ubatuba (Praia Domingos Dias) were alive more yellow without the bluish tone. The first collector of the snails near Ubatuba, Mr. Caio Del Rio Garcia, noted this difference and also observed the more yellow shade of the sand on the mentioned beach.

The resorption of the inner walls and the columella in Olivella was described by P. Fischer (1881) and Crosse \& Fis- 
cher (1882). The apex of $\mathbf{O}$. verreauxii is strongly calcified. The inner walls of the apical whorls of Oliva sayana are thin and transparent like glass. Part of their thickness is resorbed. This is visible where they pass into the thick outer walls. Here the various layers of the thick shell are laid free one beside the other as in an oblique polish. The thinning of the inner walls of the upper whorls is less conspicuous in our two species of Olivancillaria. The dropping angle of the apical whorls of Oliva sayana is rather variable; in many shells it is about $70^{\circ}$, in others up to $105^{\circ}$. Also in Olivancillaria brasiliensis this angle varies. The larval shell is distinct in our Olivella and Oliva; in Olivancillaria brasiliensis it is still just visible, also in the biggest specimens; in Lintricula auricularia it is often completely concealed by the callus. The periostracum of Oliva, Lintricula and Olivancillaria contains dark pigmeni, and therefore the slightly worn shells which are found on the beach are lighter than those of living snails and reddish brown.

Of our studied olivids Oliva, externally of almost bilateral symmetry (Morton 1958, p. 7, f. 3), has the most complete appendages. Two vertical flaps which flank the mouth bear tentacles with eyes above the middle of their height. The other appendages are an anterior and a posterior mantle tentacle and a short posterior mantle lobe. Simroth (1897, p. 153) approached the posterior mantle tentacle to the pallial caecum of Acteon. But these structures are quite different. The hollow caecum of Acteon (Fretter \& Graham 1954, p. 568) contains two ciliated ridges and lies inside the shell; the posterior mantle tentacle of the olivids is solid, glandular and lies outside the shell in the channel of the suture. A chondroid support of the posterior mantle tentacle as described for Voluta musica $(\mathrm{Pa}-$ ce 1902, p. 23) does not occur in our olivids. As Olsson (1956, p. 164) reports for Oliva also O. sayana lifts the posterior mantle tentacle out of the suture and pulls it into the shell, when the soft parts are withdrawn. In Olivella verreauxii, however, it frequently remains outside the shell, when the animal retracts due to preservation. Evidently the small operculum of our species does not close the aperture completely. 
The posterior mantle tentacle of Olivella is longer than that of the other studied species and surpasses the length of the shell. The posterior mantle lobe is broad and produces a thick callus in $\mathbf{O}$. verreauxii. An anterior mantle tentacle is present, but no tentacles nor eyes. The vertical flaps on both sides of the mouth which bear the tentacles in Oliva are developed also in Olivella, but are not innervated and thus do not substitute the tentacles. In Lintricula and Olivancillaria, also without tentacles and eyes, these flaps are supplied with nerves. Both species have no anterior mantle tentacle; Weinkauff's figures of $\mathbf{O}$. brasiliensis (1878, t. B, f. 4-5) with long tentacles, eyes, and anterior mantle tentacle are incorrect. The posterior mantle lobe is rather thick in Lintricula and Olivancillaria, the posterior mantle tentacle a little longer than in Oliva sayana. It extends nearly around the body whorl to the point where the callus closes the channel of the suture.

The siphon has smooth borders in Olivella and frilled ones in Oliva. In Lintricula and Olivancillaria (Fig. 9) they bear branched papillae, evidently functioning as filter (Clark 1958, p. 58, 62). The foot of Olivella and Oliva measures about two thirds of the length of the shell and can be completely withdrawn. In Lintricula and Olivancillaria it has twice the length of the shell and cannot be entirely retracted, even when the snails are stimulated mechanically. The expanded foot of an $\mathbf{L}$. auricularia with a $42 \mathrm{~mm}$. long shell is $80-90 \mathrm{~mm}$. long and $40-45 \mathrm{~mm}$. broad.

\section{MANTLE APPENDAGES}

Anterior and posterior mantle tentacles, posterior mantle lobe and siphon are similar to one another and alike in the examined species. The dorsal columnar epithelium of the anterior mantle tentacle of Olivella verreauxii contrasts with the flat cells of the ventral surface. Several bundles of longitudinal muscle fibres lie under the epidermis together with erythrophilous and cyanophilous glands. Nerves run in the connective tissue. Blood lacunae are scarce. 
The posterior mantle tentacle of Olivella and Oliva sayana has cyanophilous glands specially under the high and ciliated dorsal epithelium. In Oliva the glands form a voluminous concentrated mass, while Olivella possesses also a ventral accumulation. The nerve of Olivella courses between a dorsal and a ventral blood sinus. In Oliva the several nerves, in part of considerable diameter, are ventral; a large blood sinus is dorsal. The muscles in the connective tissue are dorsally and ventrally concentrated in Olivella, while those of Oliva fill up almost the whole ventral parenchyma around the mass of glands and the large sinus.

The posterior mantle tentacle of Lintricula auricularia shows many basophilous intra-epithelial glands in the high and ciliated dorsal epidermis and a few subepithelial ones under the flat epithelium of the sides. Under the dorsal epithelium acidophilous glands constitute a thick layer. Ventrally to them the longitudinal muscles form a compact stratum too. Still farther ventral lie two large blond lacunae. Between them run several nerves of different calibre. The same elements appear in the posterior mantle lobe of the mentioned species. Its muscles are more uniformly distributed and consist mainly of longitudinal and dorso-ventral fibres. The blood lacunae lie in the middle of the lobe; the nerves run near the ventral epidermis.

The siphons of Olivella and Lintricula were examined. Their ciliated borders are as said, smooth in Olivella, in Lintricula branched. In the latter species a larger blood sinus runs near each border. The connective tissue contains numerous radial muscles besides longitudinal and dorso-ventral fibres in Lintricula, while in Olivella these as well as the other muscles are weakly developed, and the interior of the siphon is vacuolized by numerous blood lacunae. Both species have a higher dorsal and a lower ventral epidermis, few basophilous intraepithelial glands, and many nerves in the ventral half of the parenchyma. Part of these is evidently sensory and supplies the subepithelial cells whose terminations form sensory, probably chemoreceptive (Yonge 1947, p. 509; Morton 1958, p. 5), 
pads on the surface of the siphonal papillae of Lintricula. The cilia of a narrow strip along the outer borders of the siphon evidently beat to the exterior. They produce the current by which heavy particles are removed from the inhalant opening (Yonge 1938, f. 1, on p. 454, "current A") described by Yonge (1947, p. 495), Fretter (1948, p. 619), and Clark (1958, p. 58). Further cilia inside the siphon or between its root on the mantle border and the ctenidium are not developed. Hence the branchial cilia produce the inhalant current as generally in pectinibranchs. Under the gill a longitudinal ciliated strip extends backwards on the floor of the mantle cavity. It is continued into a right-sided field and corresponds to the streak that leads medium-sized particles out in Buccirum (Yonge 1938 , f .1, on p. 454, "current $\mathrm{B}$ "). The right-sided field is mentioned later in connexion with the reproductive organs of Olivella .

\section{PEDAL GLANDS}

\section{Olivella}

Scattered blue staining glands occur below the ciliated epithelium of the propodium and the parapodial flaps. A dorsal and a ventral unciliated transverse furrow separate propodium and metapodium. In the female the right half of the dorsal furrow bears cilia. The anterior border of the propodium has two shallow horizontal clefts, the so-called labial clefts. Clusters of blue staining glands (ae), the anterior pedal mucous glands (Graham 1957, p. 141) lie among the connective tissue and muscles of the propodium and discharge into the clefts: (Fig. 15). The ridge between the clefts is underlain with clusters of sensory cells. The clefts disappear in the middle, because here a median furrow passes from the back of the propodium to its sole. In the female the ventral propodial furrow is indistinct. Both sexes have an unciliated metapodial sole which flattens backwards. A small group of blue staining gland cells (ra) is located at the crossing point of the ventro-median and the transverse furrows. This posterior pedal gland (Graham 
1957, p. 142) occurs in both sexes. A little behind lies the much more conspicuous ventral pedal gland of Graham's terminology, "la glande pédieuse ventrale" of Touraine (1952, p. 242), whose aperture is longer than broad. Only females have this gland (Fig. 13, 15, v), as Pace (1902, p. 22) first noted in Voluta musica. Intra-epithelial and subepithelial sole glands (Graham 1957, p. 141-142) occur in Olivella, Oliva and Lintricula. The rim of the ventral pedal gland projects outwardly in living and preserved snails (Fig. 11), while Simroth (1899, p. 262) expressly indicated such salient lips as a consequence of preservation. The shape of this pit with prominent circumference evidently led Olsson (1956, p. 161) to take it for the mouth. The surrounding sole has 12-14 micra high epithelial cells with 8-10 micra long cilia; the ventral gland is lined by an 8-12 micra high epithelium with 5 micra long cilia. This difference is common among the prosobranchs (Simroth 1898, p. 264265). As in the posterior gland also in the ventral one the blue staining secretory cells lie below the uniformly ciliated epithelium which is not glandular. The same disposition of the glandular elements was observed in the anly existing pedal gland, the ventral or female one, of Nassa (Abbott 1955: Nassarius) reticulata (Fretter 1941, p. 195). The thickness of the gland cells in Olivella is different in accordance with the reproductive activity of the individual. The musculature is composed of chiefly radial fibres. Particles are sometimes entangled in the cilia of the female pit and the sole.

Perhaps this material came from the storage vesicle of faecal matter (Fig. 45), when the egg capsule entered the.pit for being moulded and hardened. Moulding of the egg capsule was presumed as function of the ventral pedal gland by Simroth (1907, p. 993), and observed by Ankel (1929), Fretter (1941, p. 199 ff.; 1946, p. 337) and others (see Ankel 1936, p. 172; P.-H. Fischer 1950, p. 204). Besides the egg capsule is fixed to the substratum by the secretion of the gland cells; the egg capsule itself is produced by the glandular oviduct, not by the pedal gland (Graham 1957, p. 142), as still indicated by Thiele (1935, p. 1033). 


\section{Oliva}

Intra-epithelial blue staining gland cells are abundant in the ciliated cylindrical epithelium of the propodium and the lateral flaps. The dorsal and ventral transverse furrows separating propodium and metapodium, are present. The ventral one is not straight as in Olivella but forms an obtuse angle opened backwards, as described by Brock (1889, p. 74-75) and drawn by Küttler (1913, f. B on p. 480). Hence it is parallel to the anterior border of the propodium. The labial cleft is very shallow. Its epithelium consists of 25 micra high ciliated cells with cilia of the same height. It is underlain with groups of sensory cells, identical with those under the ridge in Olivella. The subepidermal glands of the anterior pedal border open above and below the sensorial furrow; they are more or less distinctly stained in different individuals.

The dorsal median propodial furrow is always present, while the occurrence of the ventral one varies. The ventral metapodial furrow is allusively developed. Both sexes possess glands that correspond to the posterior pedal cluster of Olivella. However these sub-epidermal gland cells accompany the entire angulated furrow between propodium and metapodium in Oliva.

The ventral pedal gland (Fig. 16) exists, as in Olivella, only in females. It is located a little behind the point of the angle formed by the transverse furrow. Its aperture is a nearly $2 \mathrm{~mm}$. long, longitudinal slit whose rim projects slightly. The glandular mass is $0,9 \mathrm{~mm}$ deep and broad, the lumen 0,7 $\mathrm{mm}$. deep. The walls of the cavity are thrown into folds and consist of ciliated cells and unciliated gland cells as in Fretter's muricids. The epithelium and the cilia vary in height; the cilia are longest on the crests of the folds. Subepithelial glands about $0,2 \mathrm{~mm}$. in length open among the epithelium and in $0,2 \mathrm{~mm}$. breadth on both sides of the aperture. The metapodial musculature composed of longitudinal, dorso-ventral, and transverse bundles is not much modified by the pedal gland. Some transverse fibres curve around the gland, thus function- 
ing as circular constrictors, and dorso-ventral fibres are radially disposed as divaricators.

Küttler $(1913$, p. 479,485$)$ discovered the female pedal gland in Oliva. The terms of his summary (p. 539) are vague: "In some individuals there is the rudiment of a pedal gland". Unfortunately he drew the ventral view of a snail (fig. B) with glandular slit (pap) and penis (pe). The "rudimentary" stage of the pedal gland of Küttler's species (p. 485) evidently corresponds to the non-reproductive phase of his material (p. 516), also revealed by the absence of sperms in the testis and the empty bursa copulatrix.

Among the female pedal glands of Fretter's four Stenoglossa (1941, p. 194 ff.) that of Ocenebra erinacea is similar to that of Oliva sayana.

\section{Lintricula}

Lintricula and Olivancillaria have the same transverse dorsal and ventral furrows which separate propodium and metapodium as the other examined olivids. The propodium of both has a dorso-median furrow in males and females. Also a metapodial groove occurs in both species and both sexes (Fig. 14). The crescent-shaped propodium of Lintricula is short in comparison with the metapodium and its dorsal extension is about twice as long as the ventral one. The anterior border of the propodium bears numerous sensory cells, but has no horizontal furrow. The anterior pedal glands open dorsally to the gland-free foremost projection of the propodium. The posterior pedal gland accompanies the dorsal and ventral transverse furrows as in Oliva. About $3 \mathrm{~mm}$. behind the ventral transverse furrow the above mentioned groove extends for a length of $6-12 \mathrm{~mm}$. It is $2-4 \mathrm{~mm}$. broad and $1 \mathrm{~mm}$. deep in the middle. In front of and behind this groove the sole glands are 50 micra long. Those in the groove differ considerably from them, as they are crowded and up to 200 micra long. The dorso-ventral muscles of the sole are strengthened in the area of the groove which may be used when the snail holds on its prey In the 
anterior half of the groove the gland cells attain a height of 0.4 $\mathrm{mm}$. in the middle. In adult males only few are so long and are pale, but in adult females these high cells are densely disposed and, in part, stain dark blue. Moreover some of the adult females have two shallow transverse furrows going out from the area of the central high cells. Evidently this region corresponds to the ventral pedal glands of Olivella, Oliva and other Stenoglossa, but is not so distinctly set off as in these and differs from that in the male only by the quantity of the high cells and their colourability. The ventral groove does not have the structure of a sucker as the pit in front of the ventral gland Fretter (1946a, p. 126) discovered in males and females of certain muricaceans.

\section{1 \\ 7. CENTRAL NERVOUS SYSTEM}

\section{Olivella}

The perioesophageal nerve collar lies behind the everted and below the inverted proboscis. The nerve ring is rather concentrated, but all ganglia are distinctly separated (Fig. 19). The pedal ganglia are the most voluminous centres as in Buccinum (Dakin 1912, p. 67), Harpa (Bergh 1901, p. 614), Voluta (Pace 1902, t. 2, f. 3) and other Stenoglossa (Simroth 1899, p. $412-425$, t. 29). The large pedal ganglia of the olivids correspond to the size and the biological importance of the foot as in the naticids (Risbec 1956, p. 28, 29). By means of this powerful locomotor organ the snail which lives in the dense medium of fine sand reaches its prey, its mate and the substratum to which it attaches its eggs. To the locomotor function of the foot must be added the sensory activity of its anterior border. Risbec (1955, p. 62) found the nerve ring of Oliva erythrostoma so much deflected that the flattened undersides of the pedal ganglia which are directed ventrally in other prosobranchs are turned towards the right side. In some specimens of Olivella verreauxii we have seen it so, when the nerve ring was isolated, but not in all cases, and never in the sections where the natural position of the nerve collar is maintained. 
Short connectives unite the pedal and the propodial ganglia (Fig. 15). The occurrence of the latter is a primitive feature (Krull 1935, p. 462). A propodial commissure is not developed, nor are there metapodial ganglia, as, e. g. in the primitive hydrobiids (Bregenzer 1916, p. 250-51, 271).

The cerebral and the pleural ganglion of the left side lie farther in front than the corresponding right centres. Hence the connectives between the right dorsal ganglia and the pedal and buccal ones are longer than those of the left side. The right cerebro-pedal connective is especially long $(0,15-0,2 \mathrm{~mm}$.), and some nerve cells were found on them in two of the sectioned nerve rings (Fig. 18). Of the other connectives only the right pleuro-pedal one showed some ganglion cells in one series of sections. No nerve cells were found on the commissures.

The connective which unites the subintestinal ganglion with the left pleural ganglion, the left root of the visceral loop, is strong. Also the dextral zygoneurous connection, the connective between the subintestinal ganglion and the right pleural ganglion, is thick. As in the two following olivids there are two ganglia in the posterior course of the visceral loop. The right and bigger one is located near the hind border of the mantle cavity, a little to the right of the oesophagus, the left or accessory one (Giese 1915, f. 7 on p. 180) $0,4 \mathrm{~mm}$. farther in front, to the left of the oesophagus.

The nerve cells which form the lateral caps of the pleural ganglia are similar to those of Dolium (Abbott 1955: Tonna) galea figured by Schreiber (1930, t. 1, f. 11, t. 5, f. 20, 25). These cells contain pigment and are surrounded by pigment which is, according to Schreiber, stored by amoeboid cells. The peculiar aspect in stained preparations or sections of the nerve ring is due to the red staining supporting fibres of the mighty neuroglia tissue which accompanies connectives and commissures (Fig. 15, 17). The rich development of this tissue is correlated with the feeding habits of Olivella. The snail engulfs lamellibranchs one third as long as its own shell, has small salivary glands and no crop (pharynx of Leiblein) nor oesophageal gland (gland of Leiblein). Hence the prey enters the stomach undi- 
vided and endigested, and on its way extends the oesophagus and the nerve collar. The distention of the latter is made possible, as in the tentacle nerve of Arion (Jakubski 1913, p. 114), by the neuroglia fibres. Peculiar are the neuroglia cells situated axially among the nerve fibres (Fig. 17). The processes of these cells ramify towards the periphery, where they join the external neuroglia coat (ibid., p. 109, 113). Axial neuroglia cells are frequent in the pedal commissure, in all connectives, and in the propodial nerves.

Each propodial ganglion gives origin to 4 nerves. The two thinner ones run towards the sides, the two thicker nerves form the propodial nerve net with its transverse rows of secondary ganglia discovered by Brock $(1889$, p. $70-71$, t. 6, f. 2) in Oliva maura. The sensory cells below the anterior border of the propodium are connected with the propodial nerve net. Of the numerous nerves going out from the pedal ganglia only the anterior ones were drawn; the thick penial nerve leaves the right pedal ganglion. Though tentacles and eyes are not present, the innermost cerebral nerve can be called tentacle nerve in conformity with Küttler (1913, p. 520, n. opt.). As in his species, Oliva peruviana, the nerves of the proboscis and the proboscis sheath of Olivella are more conspicuous on the left cerebral ganglion than on the right, where they, however, also exist. The static nerve is short, and the statocyst (s) lies near the brain, viz. to the side of the posterior border of the pedal ganglia (l. c., p. 524-25). The lumen of the statocyst is 66 micra in diameter, the statolith 60 micra. The low epithelium of the vesicle consists of fungiform sensory cells and vesicular cells. The capsule of the statocyst is composed of an inner layer of homogeneous supporting substance and an outer one of vesicular cells of Leydig which form a tissue similar to Schaffer's chordoid tissue (1913, text-fig. B on p. 328 ).

The short buccal connectives arise antero-ventrally from the cerebral ganglia. The buccal commissure is about as long as the diameter of each buccal ganglion (ca). The radular 
nerve leaves the commissure, and more nerves than were drawn go out from the ganglia. The columellar (cv) and the pallial-siphonal (sn) nerve (Bouvier 1887, p. 310) as well as one innervating the body wall come from the left pleural ganglion. The peripheral left zygosis (ez) between the pallial-siphonal and the osphradial-branchial nerve known of Buccinum (Dakin 1912, p. 70) and Oliva (Küttler 1913, p. 521) is present. Also the nerve of the subintestinal ganglion (un) which innervates the right mantle and the posterior mantle appendage, and the nerve from the supra-intestinal (va) ganglion to the floor of the mantle cavity are the same as in Oliva.

The nervous system of Olivella verreauxii resembles that of two Volutidae, Harpovoluta charcoti (Eales 1923, f. 37) and Cymbiola (Powell 1951: Adelomelon) anicilla (Woodward 1900, t. 10, f. 9).

\section{Oliva}

The central nervous system of Oliva is well known by the studies of Bouvier (1887, p. 309-312), Haller (1905, p. 653-658) and Küttler (1913, p. 517-523). We give a combined drawing of six successive sections (Fig. 22) and dorsal and right-side views (Fig. 20,21). The spongy mass of connective tissue which surrounds the nerve collar is stippled with brown pigment. The torsion that Risbec (1955, p. 62) described for Oliva erythrostoma was mentioned as present in some isolated nerve rings of Olivella. In Oliva sayana the deflection exists in a similar degree as in Risbec's species. The pedal ganglia which are antero-ventral to the cerebral ganglia are enormous, as big as all others together (Bouvier 1887, p. 310). All connectives are so short that the nerve cells of the ganglia touch over them. Bouvier (1. c.) evidently meant this when he stated that all connectives are. covered with nerve cells, and the ganglia are only separated by superficial constrictions. This nerve ring is too narrow for the passage of an entire snail or clam of the size of an Olivella or Donax (Olsson 1956, p. 164).

Morphologically the nerve ring of Olivella with distinct connectives and separate ganglia is more primitive than that 
of Oliva with its extreme concentration and fusion of the ganglia. But considered in relation to the alimentary possibilities the dilatable central nervous system of Olivella appears more advanced than the rigid collar of Oliva, who must feed on small prey or break its food up outside its body, exposing foot and prey to ennemies for a long time.

As Bouvier (1887, p. 311) found the nerve ring of the Marginellidae almost as concentrated as that of Oliva, he considered the marginellids nearer related with olivids than with volutids (p. 312). Fused and indistinct ganglia, except the cerebral ones, were also described for Marginella hyalina (Eales 1923, p. 38).

As in other Stenoglossa (Bouvier 1887, p. 417, 487) the statocysts lie at different distances from the nerve ring. The capsule of the statocyst has the same struture as in Olivella; its cells of Leydig contain some pigment.

The tentacles are dorso-ventrally compressed continuations of the laterally compressed oral flaps (see: alimentary tract) . Their lengths vary considerably in the examined 'specimens. The epidermis of the tentacles bears the same vertically striped cuticle as the outer side of the flaps. The tip of the tentacle is formed by a short flagellum set off from its proximal base. The eye measures $0,18 \times 0,2 \mathrm{~mm}$., the lens $0,12 \times 0,14 \mathrm{~mm}$; the pigment lies in the supporting cells. Though the tentacle nerve runs through the entire length of the tentacles and ramifies in the flagellum, the much richer innervation of the propodial border suggests that also in Oliva this border is the most important sense organ as in Natica (see: Ankel 1936, p. 140).

\section{Lintricula}

The central nervous system of this species (Fig. 23-25) is brick red, due to pigment in its outer neuroglia and the nerve cells that cover a great extension of the cerebral (cr) and pleural (ua) ganglia. These centres are broadly coalesced. The remaining connectives and commissures are distinct, shorter than in Olivella, but much more distinctly set off than in Oliva. The supporting neuroglia fibres are chiefly developed in the con- 
nectives and occur also in the propodium. This highly extensile and contractile organ whose function substitutes the wanting tentacles is supplied by eight nerves, four originating from each propodial ganglion. These nerves ramify and anastomose and form about 8 series of consecutive secondary ganglia. The longitudinal conectives of these ganglia are enveloped in a neuroglia containing the above mentioned fibres which allow for rapid movements of the propodium. As in the other examined olivids the pedal ganglia (en) are the most voluminous centres; including the primary propodial ganglia (se) their mass is about the same as that of the other ganglia together. The flat underside of the pedal ganglia is parallel to the foot, not deflected as in Oliva. The left cerebro-pleural ganglion lies farther in front than the right one as in Olivella.

Also the position of the statocysts (s) is asymmetrical, as the right is farther distant from the nerve collar than the left. The capsule of the statocyst is formed by a dense fibrillar connective tissue with scarce nuclei whose periphery is intermingled with cells of Leydig. The lining of the statocyst corresponds to Küttler's description (1913, p. 525-526) of Oliva. There are two types of cells, dark staining ones and between them others which appear empty in the sections. The dark staining cells broaden distally and partly overlap the adjacent pale cells. Every dark cell bears one long sensory hair. Küttler considers the pale cells as supporting cells, but they look rather like secretory cells. The description of the epithelium of the statocyst applies also to our Olivella and Oliva sayana. All our olivids have one big spherical statolith.

\section{ALIMENTARY TRACT}

\section{Olivella}

The oral flaps (Fig. 30, mv) are small cutaneous projections whose inner surface is ciliated. The interior of the flaps contains muscle fibres and some loose connective tissue, a blood vessel and some lacunae. The mouth (mo) lies under the right flap. A short narrow oral tube connects this outer opening of the gut with the proboscis sheath (sz). The sheath is almost 
completely turned inside out, when the proboscis is everted (Fig. 15) . The introverted sheath extends dorsally farther backwards than ventrally and attains the level of the gill. The proboscis is often turned round, hence the pharynx is dorsal in Fig. 15, and the oesophageal loop may occupy any position when the proboscis is introverted.

The two lateral radular cartilages (rs), better cushions of supporting tissue (Schaffer 1913, p. 372), are separate on their entire length. Over them the cuticular radular membrane (Fig. $31, \mathrm{ru}$ ) passes on to the lateral walls of the pharyngeal cavity. The radula (Fig. 26, 32) consists of about 35 rows of 2.1 .2 plates. Thiele (1931, p. 372) considers the 2 lateral plates as one medial, curved and pointed cusp (q) jointed with a lateral rectangular base (az). We prefer to follow Fischer (1887, p. $599)$ and Olsson (1956, p. 169) who speak of two lateral plates, calling Thiele's base an accessory plate. In some subgenera of Nassa (Nassarius) a plate without cusp is known (Simroth 1901 , f. 122 e on p. 476 ). It lies between rhachidian and lateral plate, not outside or under the latter as in Olivella. The middle plate is $0,12 \mathrm{~mm}$. broad and bears $20-35$ denticles of different size which vary individually. Among nine radulae two medial denticles were the biggest in eight cases, only once a single median denticle was strongest. Between the two medial denticles 1-3 minute ones occur.

Contrary to the rule in Stenoglossa the primary salivary, better pharyngeal, glands (ss) are short ramified tubes which come from both sides and open unusually far in front into the beginning of the pharyngeal cavity. Tubular salivary glands were found in Marginella hyalina (Eales 1923, p. 38). The glands of Olivella verreauxii are formed of big cells whose number is 4-6 in a transverse section. Their secretion is basophilous. The cells of the quite short duct are smaller, more numerous and ciliated. As in some other Stenoglossa, e. g. Buccinum and Harpa, there are no secondary (accessory) salivary glands. The mentioned snails feed in a quite different manner from our Olivella. 
The oesophagus (o) whose foremost part is called proboscis gut (Küttler 1913, fig. L, RD), is continuous with the dorsal channel of the pharyngeal cavity. When the proboscis is retracted, the anterior oesophagus runs forwards from its inner end. This anterior oesophagus is lined with columnar ciliated cells, and contains some mucous glands and smaller ones with red staining secretion. This epithelium forms about eight rather uniform longitudinal ridges, so that the transverse section appears stellate. The three stars drawn in the ascending limb of the oesophagus in Fig. 30 show the torsion in which this part of the alimentary tract is involved by the torsion of the visceral mass (Graham 1939, p. 76 and elsewhere), though as in Buccinum (id. 1941, p. 12) distinct dorsal folds cannot be defined.

In some specimens the anterior oesophagus suddenly enlarges in front of the nerve ring. The epithelium of this expansion (Fig. 33) contains more numerous gland cells, deep folds are developed on the topographically ventral side, and the musculature thickens. The folded, phylogenetically dorsal side has more red staining gland cells than the smooth ventral side, but the histological difference between both sides is insignificant. This little differentiated and individually inconstant dilatation of the oesophagus corresponds to the pharynx of Leiblein (pyriform organ) known in Muricacea, Buccinacea (absent in Fasciolariidae Simroth 1901, p. 515) and Oliva. According to Bergh's figures (1901, t. 47, f. 2, 3) of the outer aspect of the gut an only allusive pharynx of Leiblein seems to occur in Harpa too.

In the oesophagus behind the nerve ring a mid-oesophagus and a posterior oesophagus (Graham 1941) cannot be distinguished, because there is no oesophageal gland (gland of Leiblein). The eight oesophageal folds of the backward course are lower than those of the anterior limb and flatten in the middle: farther backwards they increase again. The epithelium of the postneural oesophagus containing two types of gland cells is the same as in front. The absence of an oesophageal gland olivella verreauxii has evidently in common with the species of Harpa studied by Bouvier (1887, p. 311) and Bergh (1901). 
As in the higher mesogastropods (Taenioglossa) and Stenoglossa (Graham 1949, p. 755) the oesophagus opens into the topographically anterior end of the stomach, near the intestine (Fig. 34, 36). The short oesophageal region of the stomach bears longitudinal ridges which are prolongations of those running along the hind end of the oesophagus. Medially the area of these ridges is limited by a thick fold (os) which leads the food to the fundus. This large triturating area (ie) occupies about two thirds of the entire stomach. Its lining cuticle (uc) and longitudinal and annular muscle layers (mz) characterize this region as gizzard. Cuticle and annular muscles are especially thick in a broad ectal belt of the gizzard (Fig. 35). The crushed food passes along the medial side of the thick fold to the posterior sorting area (re), a small field of transverse folds which, at least in part, bear cilia. This area communicates with the common opening of the ducts (d) from the digestive gland and with the intestinal groove (ir), the latter flanked by the major (mi) and minor (mu) typhlosoles. The epithelium of the hepatic ducts is similar to that of the stomach (Küttler 1913 , p. 506), not to that of the acini (ui). The epithelium of the latter consists of digestive cells and very rare lime cells (Graham 1938, p. 279).

The peri-intestinal connective tissue (Fig. 37, rc) forms a thick pad around the region of the sorting area, intestinal groove and duct of the digestive gland. It consists of indifferent cells and scattered clusters of cells with intensely red staining plasma. The same type of cells occurs as free amoebocytes in the body cavity, and some similar elements were seen in the epithelium of the gut in this region. They are evidently the wandering phagocytic cells mentioned by Morton (1953, p. 243, f. $1,2, \mathrm{PH})$. Storage and conduction of alimentary substances by the peri-intestinal connective tissue was indicated by Haller (Simroth 1899, p. 295).

Of the stomachs examined by Graham (1949) that of Nassa (Nassarius) reticulata (p. $749, f .22$ ) is the least different from that of Olivella verreauxii. The great extension of the sclerosed surface of the stomach in Olivella is certainly secondary. 
The anus lies on the topographically right side of the pallial cavity, behind the hypobranchial gland and in front of the female pore. An anal gland is not developed.

\section{Oliva}

As in the other examined species there are two vertical dextro-sinistrally compressed oral flaps. Their epidermis is ciliated on the inner surface and coated with a striped cuticle ("Bürstensaum") on the outer side. This cuticle, the thicker epidermis and its more numerous glands; the stronger musculature and the innervation distinguish the flaps of Oliva from those of Olivella. The blood vessel and the lacurae are the same. Both flaps are grown together at their bases, and the mouth lies in the middle under this connection.

The following description contains principally additions to Küttler's good study (1913, p. 494-511) or mentions differences, possibly of specific character. The oral tube of Oliva sayana (Fig. 38) is short and wide; the proboscis sheath (sz) may be almost completely everted. The backward extension of the inverted sheath is the same on all sides. The retractors of the proboscis (vo) originate with branching bundles on the body wall and insert, ramifying again, on the anterior part of the sheath (1. c., p. 495). The wall of the sheath is in front thinner than that of the proboscis. The latter is thin below the pharynx. Sheath and proboscis wall thicken towards the base. The mucous glands of the proboscis dwindle towards the tip, and are dense in the region where the wall of the proboscis passes to that of the sheath, and where lubrification is especially needed. As in Olivella verreauxii also in Oliva sayana the everted proboscis is much shorter than the shell.

The radula (Fig. 27) is $3,3 \mathrm{~mm}$. long, $0,36 \mathrm{~mm}$. broad, and contains about 120 rows. The $0,15 \mathrm{~mm}$. broad rhachidian plate bears two big lateral and one smaller median cusp; the lateral plates are broad at the base and pointed at the tip. The radular membrane spreads over the separte cushions of supporting tissue as in Olivella. Different from this fast cuticle is the 
thick and soft one that coats the tip of the proboscis and covers also the high columnar epithelium of the odontophore (rotella). The dorsal food channel and the lateral walls of the pharynx are free from cuticle.

The foremost opening (oa) of a salivary (pharyngeal) gland is that of the unpaired, accessory gland which discharges into the bottom of the proboscis tube near the tip. The paired, primary glands (ss) open laterally (ov), $0,16 \mathrm{~mm}$. the one and $0,46 \mathrm{~mm}$. the other behind the orifice of the accessory gland. The thin duct of the latter runs backwards to the root of the proboscis along its floor and ventrally to its artery. Farther behind this duct lies between the oesophagus and the artery, flanked by the ducts of the primary glands. At the level of the pyriform organ the duct of the unpaired gland is connected with the simple acinus (as), the "coecum glandulaire impaire" (Risbec 1955, p. 50), whose length is individually different The primary glands are branched and coiled tubules; their ducts contain a thick bundle of fine threads of secretion.

The dorsal folds are already marked by the salivary ducts and continue distinct to the sides of the dorsal food channel approximately to the end of the proboscis. The ciliated columnar epithelium of the anterior oesophagus contains only very few mucous glands. Light blue staining vacuolized ovoid cells with small nuclei, possibly phagocytic cells, occur in the lumen of the anterior oesophagus and in its epithelium. The same cells were also seen between the perioesophageal muscle fibres. Millott (1937, p. 185, 187) and Fretter (1939, p. 608, 614) found wandering amoebocytes in the oesophagus of opisthobranchs.

Behind the root of the proboscis the oesophagus bends forwards and its epithelium is thrown into a number of equal folds, so that the dorsal folds are no longer recognizable. This course of the anterior oesophagus has several dilatations with more or less thinned walls. It widens suddenly (no) into the pharynx of Leiblein (pyriform organ) which is really pyriform, thick in front and thin behind. A yellow transparent spiral around its anterior surface is the mucous pad (Graham 1941, 
p. 6) with a ventral interruption. The pad surrounds the base of the glossy cone which projects into the cavity of the pyriform organ and is formed by a dorsal reduplication of the anterior oesophagus. The high epithelium of the pharnx of Leiblein has basal and apical nuclei (Küttler 1913, p. 499) pertaining to unciliated columnar glands and slender ciliated cells respectively (Graham, 1. c.). The dorsal folds reappear in the pyriform organ, flanking a cleft at the topographically ventral side. The latter wanders over the right to the dorsal side, attaining the median plane at the end of the pyriform organ. As in the Muricacea (Graham 1941, p. 4-5) the ventral cleft is seen from the outside.

Behind the nerve ring or in other specimens even at the hind end of the pyriform organ the short mid-oesophagus shows a whitish thickening (io) of the dorsal folds. The epithelium is so high that it restricts the oesophageal lumen to a dorsoventral slit. The cells are ciliated and glandular, as in the pyriform organ, but the glands stain pink in the latter and blue in the mid-oesophagus. The flat, not glandular, epithelium of the ventral wall is bordered by two ridges. The high epithelium enters the duct of the oesophageal gland (gland of Leiblein), where it was found in O. peruviana by Haller (1905, p. 660), not by Küttler (1913, p. 503). From the duct the glandular epithelium spreads far into the ramifications of the oesophageal gland (oe). The latter is similar to that of Nucella (Graham 1941, p. 10). It is subdivided internally into many small lobes. In each lobe the club-shaped secretory cells are in the same phase of secretion, high and almost obliterating the lumen, or mediumsized with few granules, or quite short with detached ends. These fill the centre of the lobes as spherules containing granular secretion and are also found in the posterior oesophagus on their backward course.

At the level of the posterior border of the mantle cavity the posterior oesophagus is approximately in its middel fastened to the ventral wall of the body cavity by a ring of muscle fibres (om). At this point the efferent duct passes over the 
oesophagus. High pink staining glands, single blue ones, and ciliated cells with brown pigment constitute the epithelium of the posterior oesophagus, whose hindmost part shows about 16 high longitudinal folds. In the summits of the largest of these runs an artery. The oesophagus enters the stomach through a constriction a little behind the pyloric region.

The very much modified stomach of Patella vulgata (Graham 1949, p. 749) confirms Simroth's statement (1901, p. 529) of the discrepancy between the usual systematic arrangement and the anatomy of the stomach. This statement applies also to Olivella and Oliva. In the latter one would expect a simplified stomach in correlation with the complexity of the secretory pharyngeal and oesophageal glands (Fretter 1939, p. 640; Morton 1953, p. 244), but actually the stomach of Oliva is not simple. It contains even more of the landmarks known by Graham's studies $(1939 ; 1940)$ than that of Olivella.

The stomach of Oliva sayana is longer than that of $\mathbf{O}$. peruviana (Küttler 1913, fig. $N$ ), and its form varies individually (Fig. 39,41). When it is collapsed in hungry animals, the stomach forms a long caecal extension (ce) as in Littorina littorea (Graham 1949, p. 747). A fold extends from the entrance of the oesophagus to the common opening of the liver ducts. The big median longitudinal fold (os) originates near the major typhlosole ( $\mathrm{mi}$ ). The fundus is longitudinally folded, and irregularities of these folds may produce small villosities. Backwards the folds flatten out if the stomach is distended by food. Dorsal to the cardia a more strongly folded field corresponds to the posterior sorting area (re). The origin of the minor typhlosole $\mathrm{mu}$ is connected with the major typhlosole. The latter borders a small cuticularized gastric shield (si). The intestinal groove (ir) begins in the stomach with a soft and smooth concavity which corresponds to a style sac (wi). In one of the opened stomachs this region contained a rod of mucus studded with faecal particles, a protostyle (Morton 1953, p| 251). There are some transverse folds in the course of the style sac. On the outside the pyloric region is surrounded by clusters of peri-intestinal connective tissue. 
In the terminal part of the intestine its epithelium is rich in red staining glands, and the cilia of the high coiumnar cells are long. An extremely small tubular anal gland (an) $1 \mathrm{~mm}$. long and 40 micra in diameter was found only in serial sections of the anal region. The gland opens beside the anus into the mantle cavity as in Oliva peruviana, where it is much bigger (Küttler 1913, p. 506-07). Behind the anus the mantle cavity forms a tubular prolongation.

\section{Lintricula and Olivancillaria}

The oral flaps agree with those of Oliva sayana regarding the thick, glandular epidermis, strong muscles, innervation, blood vessel and blood lacunae. The cuticle of the outer surface described in Oliva is not developed in Lintricula, Olivancillaria and Olivella, but as in the latter and Oliva the inner side is ciliated. The mouth lies under the right flap as in Olivella.

The alimentary tract has the same subdivisions and glands as in Oliva. The retractors of the proboscis are simpler, not so much branched. The posterior end of the proboscis is broader open than in Oliva (Fig. 40). As in the previously treated species the proboscis is much shorter than the shell.

The radula (Fig. 28) contains 136-140 rows. The rhachidian plate has a smaller centrai cusp and two bigger lateral ones and besides an outermost small cusp on each side. This is a simple pcint in Olivancillaria (Fig. 29) and a tricuspidate saw whose denticles diminish outwards in Lintricula. In the latter the inner borders of the big lateral cusps have occasionally a minute point near their base. The lateral plates of both species are similar to those of Oliva.

Pharynx, pharyngeal glands and oesophagus of Lintricula are not so tightly wrapped in connective tissue as in Oliva. Specially the ducts of the paired glands run free, not connected with the oesophagus, and also the duct of the unpaired gland (as) courses independently. The glandular pharynx of Leiblein (no) has the same pyriform aspect as in Oliva. The whitish glandular thickening (io) of the dorsal oesophageal folds be- 
gins behind the nerve ring and extends into the duct of the oesophageal gland (oe), and also for a certain distance into the oesophagus behind the entry of that duct. In other specimens there is no posterior extension, but the thickening goes farther into the oesophageal gland. The latter is a tube winding around the cephalic aorta. The posterior oesophagus is fastened to the ventral body wall by a muscle ring as in Oliva.

The stomach is characterized by a ciliated smooth furrow which leads from the entrance of the oesophagus to the liver ducts and to the pyloric region. The liver ducts branch immediately outside the stomach. A food string was seen in the intestinal groove. A gastric shield is not developed. The intestine contains sand and blackish faecal masses. About $0,4 \mathrm{~mm}$. from the anus a $0,9 \mathrm{~mm}$. long and 40 micra thick anal gland opens into the rectum.

The mantle cavity is prolonged at its right posterior corner. This pouch subdivides into three finger-like tubes which border the rectum. Oliva and Olivancillaria have only one pouch. In Oliva, Lintricula and Olivancillaria a small papilla occurs beside the anus.

The alimentary tract of Olivancillaria is similar to that of Lintricula. The posterior end of the proboscis is even broader open than in that species. The radula comprises 134-136 rows. Particularities of the stomach are: the strong longitudinal fold descending from the opening of the oesophagus into the caecum is dorsal to the openings of liver and oesophagus; a rather shallow furrow runs from the caecum to the hepatic opening and a deeper one from there to the intestinal groove. Both furrows embrace the posterior sorting area. The intestinal groove begins with a broad, smooth and deepened area. This region is outwards surrounded by a belt of peri-intestinal connective tissue. As gastric shield is absent as in Lintricula.

\section{REPRODUCTIVE ORGANS}

Our species contain mature germ-cells; nevertheless animals collected in only one season cannot inform about the cy- 
cle of the generative organs. Of Olivella verreauxii we had material from spring (November) and winter (August), and based the description on the former. As the winter material might be affected by the season, we compared the receptaculum seminis and the internal vesicle with their state in November, but did not find any differences.

\section{Olivella, male}

The testis (Fig. 42, $\mathrm{t}$ ) begins near the apex, behind the liver and extends into the penultimate whorl. The acini of the testis shine through the tunica. The coiled testicular duct (ns) is distended with sperm and functions as vesicula seminalis (Fretter 1941, p. $175,178,179)$. A great part of the sperms is atypical and similar to the atypical spermatozoa of the conids (Bergh 1896, p. 95-97, t. 10, f. 220; Ankel 1930, textfig. 47, a). The cubical epithelium of the seminal vesicle bears scattered cilia. The following region, the short renal spermiduct, is narrow, straight and courses along the columellar muscle. The renal spermiduct is regularly ciliated. As a remnant of a gonopericardial duct (Fretter 1941, p. 175) a short strand of connective tissue passes from the spermiduct to a long and narrow diverticulum ( $g$ ) of the pericardium (er); the wall of the spermiduct is not modified. The cilia become stronger and more numerous in the pallial portion of the spermiduct. This part begins with a broad, densely ciliated pouch (so) which is in open communication ( $\mathrm{sm}$ ) with the mantle cavity. The strong cilia of the pouch continue on to the floor of the pallial cavity. These cilia constitute an efferent strip which comprises the anus and ends at the outer right border of the pallial cavity. Under the beginning of this ciliated area lies the bigger of the two visceral ganglia; the smaller or accessory visceral ganglion lies farther in front and to the left. The cyjindrical pallial spermiduct (sa) continues under the floor of the manie cavily. Iite nigh epithelium of this prostatic part consists of cells with eosinophilous granular secretion and basal nuclei and slender supporting cells with distal nuclei and with cilia. The prostatic duct courses nearly straight forwards. At the level of the nerve ring it cur- 
ves to the right and enters the long penis (vr), where it continues secretory nearly to the tip. In the penial spermiduct (te) the muscles are stronger than farther entally. The male opening is a little subterminal, it lies 20 micra below the tip. The penis (Fig. 43) is dorso-ventrally flattened and $7 \mathrm{~mm}$. long in a snail with a $10 \mathrm{~mm}$. long shell. Tucked into the mantle cavity the penis lies behind the ctenidium (k), parallel to the border of the latter and attins the posterior angle of the cavity. In the retracted penis the spermiduct is located on the left side, the nerve (vn) and the blood spaces (oc) are situated to the right. In the distal half of the penis the epidermal cells of the dorsal side are ciliated. Blue staining epidermal glands reach under the subepidermal muscles and between the latter lie numerous branches of the penial nerve.

\section{Olivella, female}

The ovary is located in the two uppermost coils behind the liver. The first part of the oviduct, the ovarian duct (ou), is lined with a low unciliated epithelium and runs beside the columellar muscle. It is very dilatable, as is shown by the voluminous eggs (Fig. 44, c) in it. The following portion, the renal oviduct (rv), is folded and ciliated. Farther ectally the gonopericardial duct $(\mathrm{g})$, which begins with a sphincter (vs), leaves the renal oviduct. The gonopericardial duct is unciliated and passes to the low epithelium of the pericardium (er) without limit (cf. Krull 1935, p. 436).

The pallial oviduct differs from that of Oliva by the external separation between albumen (aa) and capsule gland (c), both of which located in the body whorl. Also the receptaculum seminis ( $\mathrm{rn}$ ), whose position between albumen and capsule gland is identical in both species, differs by shape of that of Oliva. In Olivella it is a ciliated duct without a terminal dilatation. Sometimes its epithelium is slightly undulated by variations in the depth of the underlying connective tissue. The sperms lie principally in its blind end, some of them also in the duct. The disposition of their heads towards the wall, the tails towards the lumen, is typical for a sperm-storing or- 
gan. Ingestion of sperm by the wall cells of the receptaculum was not seen. The capsule gland has a transversely flattened lumen as that of Oliva, but its direction is dorso-ventral only in the middle part of the organ. In its ental and ectal parts the lumen extends from the right to the left side. This torsion of the capsule gland is not correlated with the coiling of the body. The sperm channel (Fig. 46, sr) lies entally on the right, in the middle on the ventral, and ectally on the left side. The angle lodging the sperm channel is characterized by longer cilia and lower cells, and separated from the lumen of the capsule gland not by folds as in Oliva, but only by stripes of unciliated low cells on both sides. These stripes are distinct from the high and ciliated epithelium which lines the capsule gland and is pierced by strands of secretion of the underlying glands disposed in rows. These secretory cells are cyanophilous in the smaller ectal section of the capsule gland and acidophilous in the larger ental part. In the middle of the latter there are two antero-posterior stripes of blue staining slands opposite to one another.

The outermost part of the capsule gland (we) has no secretory cells. This vestibule (Fretter 1941, p. 281) is wide and strongly ciliated. It is connected by a narrow passage with the likewise ciliated outer part. The latter has a posterior 0,15 $\mathrm{mm}$. deep pouch (vc) with a little fewer cilia. Opposite to this pouch and farther ectally, immediately behind the female aperture, begins a long and narrow ciliated duct (uv). It runs inwards connected by its coat of connective tissue with that of the capsule gland, whose tubules sometimes enclose the duct. The duct leads to a vesicle (iv) located behind and to the left of the capsule gland. This vesicle is $0,5 \mathrm{~mm}$. long and broad and $0,4 \mathrm{~mm}$. high. Its wall (Fig. 45 ) consists of a high cylindrical unciliated epithelium with basal nuclei surrounded by a thin musculature. The vesicle appears as a brown lump through the skin of the snail after its shell is removed. The contents of the vesicle are identical with amorphous masses of faeces which form a grumose ball. Broken skeletons and small entire diatoms, as well as fragments of sponge spicules occur in this mass, 
but not any sand grains, though such are frequent in the faeces. Probably the heavy sand grains ejected from the anus sink down on to the cilia which produce the efferent current. Some particles of the contents of the internal vesicle lie in vacuoles of the epithelial cells. The blind end of the receptaculum seminis is apposed to the vesicle, but the lumina do not communicate. The female aperture (eo) lies in the posterior angle of the mantle cavity behind the anus. A ciliated streak begins at the female aperture, encloses the anus and continues to the opening of the mantle cavity on the right side. It is the same as the efferent streak in the male where it leads out faeces and possibly an excess of sperm and prostatic secretion. Only in females the ciliated strip continues outside the pallial cavity extending to the ciliated right half of the dorsal furrow between pro and metapodium and to the mouth. Presumably these cilia.lead the egg capsule to the neighbourhood of the ventral. pedal gland.

The unciliated and the ciliated section of the oviduct are the ovarian and the renal oviduct of many gastropods. Linke (1933, p. 27) called them pseudoviduct and oviduct in Littorina obtusata. Often the renal oviduct is the site of fertilization (Fretter 1956, p. 37\%), hence the folded part of Olivella may serve as fertilization chamber. However sperm did not lie in this part in our sectioned females, though the ovarian duct already contains eggs near its end. The oviduco-coelomic funnel (Bourne 1908, p. 840), since Giese (1913; 1915, p. 180) called gonopericardial duct, Olivella has in common with the four stenoglossan species studied by Fretter (1941). The sphincter of the gonoducal side of this duct may prevent the passage of sperm into the pericardium. The homologies and functions of albumen gland, receptaculum seminis and capsule gland with Fretter's Stenoglossa and with Oliva need not be discussed. Also the homology of the pouch ( $\mathrm{vc}$ ) with the corresponding organ of Oliva, where it is smaller (Fig. 48), and the copulatory bursae of Fretter's species is obvious. In Olivella it might be a sperm-receiving organ, perhaps together with the vestibule. 
The internal vesicle stores faeces, and these are evidently led to it from the neighbouring anus by means of the cilia in its duct. We cannot explain the biological significance of the incorporation of faecal particles by the epithelium of the vesicle. The occurrence of faecal matter in the pedal gland was mentioned in our description of this gland. We suppose the function of the vesicle of Olivella to be the same as that of the crystal sac (Bourne 1908) in the Neritidae. This is the storage of particles to be spread over the egg capsule (Risbec 1932, p. $361,363$, f. 3,4$)$ as described by Andrews $(1933 ; 1935 ; 1937)$ and Risbec (1937; 1942, p. 24-25). Hence the vesicle of Olivella would be analogous with the reinforcement sac of the neritids. In this organ of Theodoxus fluviatilis Fretter (1946, p. 319) distinguished an anterior, ciliated conducting part, and a muscular, unciliated storing fundus.

The internal vesicle of Olivella and its duct are homologous with the bursa copulatrix and its canal in Oliva (Fig. 48) and Lintricula (Fig. 54). The tubular distal part in the olivids dealt with here, and the opening independent of the female pore in Olivella differ from the distal bursae in the Stenoglossa studied by Fretter (1941) and Johansson (1957, f. 4, 7), and in the other species mentioned in our introduction. As an exact homology of these organs cannot be established between the olivids on one side and the other examined Stenoglossa on the other, it is perhaps imprudent to extend the discussion to Haller's "Uterus-Enddrüse" (see Simroth 1904, p. 615) or to that of Bithynia tentaculata (Ankel 1924, p. 4), which Krull (1935, p. 448) homologized with the crystal sac. Bourne (1911, p. 804-805) warned against phylogenetic combinations based on similarities of reproductive appendages in gastropods, whose other organs, e. g. nerves and radulae, are widely different. Also Johansson (1947, p. 107) searches for homologies of accessory genital organs only in systematically related families.

\section{Oliva, male}

The testis (Fig. 47, t) which begins apically and extends into the penultimate whorl contains typical and atypical sperms 
mingled. The latter are similar to those of Olivella. The testicular duct is a coiled vesicula seminalis (ns) as in Olivella. This part is muscular and its unciliated epithelium encloses brownish yellow granules as the kidney and other organs of the species. Unrolled the testicular duct is $12-15 \mathrm{~cm}$. long; it contains the typical sperms mostly with their heads nearer to the wall and the atypical ones in the middle. The outer portion of the seminal vesicle is near to the pericardium (er), and the straight and short renal spermiduct goes on in the same position. A remnant of a gonopericardial duct is developed in the form of a pericardial diverticulum ( $g$ ) which ends blindly at the renal spermiduct.

The renal spermiduct passes into the pallial spermiduct which begins with a pouch-like dilatation (so). The broad anterior opening $(\mathrm{sm})$ of this pouch communicates with the itantle cavity under the ofroad aperture of the kidney. As in Olivella this communication does not show vestiges of its origin from an open groove. Farther forwards the closed prostatic pallial spermiduct ( $\mathrm{sa}$ meanders under the floor of the mantle cavity. Its musculature is much thicker than in Olivella. Its cylindrical epithelium with basal nuclei and evidently unciliated, stores pink staining granular secretion produced by glands which lie outside the muscles. The dorso-ventrally flattened penis (vr) is similar to that of O. peruviana (Haller 1905, textfig. $3 \mathrm{~B}$; Küttler 1913, fig. D, on p. 512), though the winding spermiduct of $\mathbf{O}$. sayana is located somewhat to the left side. The duct is lined by an epithelium storing pink granules. Blue staining glands send their strands of secretion through the very strong musculature. The number of these glands increases outwards, where the very high epithelium stores blue and pink secretion. The penial nerve lies to the right as in Olivella; blood lacunae are developed on both sides of the spermiduct. The outermost part of the duct is ciliated; its opening is terminal, contrary to $\mathbf{O}$. peruviana, whose opening lies on a subterminal papilla (Küttler 1913, p. 511). The cutaneous glands of the penis end $1,5 \mathrm{~mm}$. from the tip; the entire skin of the penis is unciliated; its muscularis is strong. 


\section{Oliva, female}

The ovary lies as in Olivella. As there and in many other prosobranchs (Linke 1933, p. 28) the structure of the ental or ovarian duct (Fig. 48, ou) resembles that of the gonad. The ectal portion (rv) which corresponds to the post-torsionally right kidney (l. c., t. 8, f. 81) has a vacuolized epithelium similar to that of the kidney. Cilia appear only where the renal oviduct enters the albumen gland (aa). The gonopericardial duct $(\mathrm{g}$ ) is unciliated. Albumen and capsule glands (c) stain differently in the sections, but are not separated externally 'The receptaculum seminis ( $r n$ ) consists of a cluster formed by about four vesicles with short stalks surrounded by a common coat of connective tissue (Fig. 49). Each vesicle has its own musculature. The epithelium is low and ciliated. The heads of the numerous sperms are attached to the wall. Incorporation of sperm by the epithelium was not seen. The common orifice of the ducts is located in the dorsal angle of the pallial oviduct, at the limit between albumen and capsule gland. The latter has the same compressed transverse section as in Olivella and Fretter's Stenoglossa (1941, f. 5), and the same ciliated epithelium pierced by the strands of secretion of the underlying gland-tubules. Küttler's section of the "oviducal gland" of O. peruviana (1913, f. J, on p. 513) shows essentially the same structure. Glandular tubules occur in the albumen and the capsule gland; the ventral gutter or sperm channel runs only along the capsule gland. There it is set off from the lumen as a T-shaped fold on the side opposite to the orifice of the receptaculum. Some single sperms were seen in the ventral channel, whose position is, contrary to Olivella, the same along the whole capsule gland. The cilia become scarce towards the outlet of the glandular oviduct, where also the glands end. This part, the vestibule, forms a shallow backward pouch containing unorientated sperm. The narrow canal between the vestibule and the mantle cavity bears strong cilia.

Opposite to the pouch a ciliated canal (b) goes out from the vestibule. This duct is enveloped in a thick mantle of an- 
nular and longitudinal muscles and projects into the lumen of a vesicle (cc). This opening lies on the left side of the vesicle and far inwards, not at the bottom. The ample vesicle is located in the thickness of the posterior wall of the mantle cavity, the rectum being dorsal to and a little in front of it. The wall of the pallial cavity beside the female aperture is bulged outwards by the vesicle. Its epithelium is unciliated; in the region of the entrance of the canal it is underlain by vesicular connective tissue. The cells that line the vesicle are secretory with distal vacuoles and basal nuclei. Some glands are depressed and reach beyond the musculature. The latter is evidently stretched by the massy contents of the vesicle, which consist of sperm and eosinophilous secretion. Sperms were not seen within the epithelial cells.

According to the position of the sperms (Johansson 1939, p. 336-337) the sperm-storing organ of O. sayana and Olivella verreauxii was called a receptaculum seminis. Fretter (1941, p. 206) said that the ingesting gland of her four stenoglossan species is homologous with a receptaculum. Later on (1951, p. 575-576) she found signs of sperm digestion in the double receptaculum of Cerithiopsis tubercularis. Johansson (1957, p. 89-90) ponders the possibility that the ingesting gland of the Muricacea and Buccinacea is a proximal bursa, and that these Stenoglossa have no receptaculum. But Fretter's view is supported by Olivella and Oliva, whose receptacula lie exactly as the ingesting gland of Fretter's species. The helc following Lintricula shows the morphological identity of receptaculum seminis and ingesting gland clearly.

Unoriented spermatozoa and secretion, in part evidently produced by the prostatic pallial spermiduct, characterize the voluminous vesicle of $\mathbf{O}$. sayana as bursa copulatrix in the sense of a sperm-receiving organ. We suppose that the penis is inserted into the long and muscular bursal canal which functions as a vagina. The vestibular pouch of $\mathbf{O}$. sayana, though homologous with that of Olivella verreauxii and the distal copulatory bursae of the Muricacea and Buccinacea (Fretter 1941), is much too small to receive the voluminous penis. The sperms found 
in this pouch may have come from the passage of sperms out of the bursal canal to the ventral channel of the capsule gland. The function of the vestibular pouch of $\mathbf{O}$. sayana is not known; possibly the egg capsule lies here before it is transferred to the pedal gland. The bursa copulatrix of $\mathbf{O}$. sayana is analogous with the distal bursae of the Muricacea and Buccinacea. The long bursal canal might be correlated with the narrowness of the mantle cavity in Oliva (cf. Johansson 1953, p. 2).

The shape of the receptaculum seminis of $\mathbf{O}$. sayana differs from that of O. peruviana (Küttler 1913, p. 512). Also two species of Trivia have different receptacula (Fretter 1946, p. 328) . We do, however, not think that the receptaculum of peruviana really opens into the renal oviduct, as must be inferred from Küttler's description (1913, p. 512 514, fig. E). The "uterus" and the "uterus gland" of $\mathbf{O}$. peruviana correspond topographically to the bursal canal and the bursal vesicle of $\mathbf{0}$. sayana. "Uterus" and bursal canal also agree histologically. In Küttler's diagram (fig. E., on p. 513) the diameter of the bursal canal (ut) differs from the much narrower of our species. This might be a specific difference, as such are known for the female organs of many species (cf. Johansson 1939, p. 334, 386). The much smaller bursal vesicle of $\mathbf{O}$. peruviana (Küttler 1913, p. 513: fig. E, ut. dr.) compared with our sayana seems to be functionally conditioned. The secretory activity of the epithelium (l. c., fig. $\mathrm{H}$ ) is much less intense than in our material, and no sperm was seen in the bursal vesicle of peruviana. Our females were evidently preserved a short time after copulation and have the bursal vesicle mightily distended. As in the Hydrobiidae (Krull 1935 , p. 439) the secretion in the bursa is on its height in the period of reproduction also in Oliva. Secretory bursae are known in many mesogastropds (e. g. Fretter 1956, p. 377; Johansson 1953, p. 2) and the neritid Theodoxus fluviatilis (Fretter 1946, p. 319). In the stenoglossan Nucella (Abbott 1955: Thais) lapillus, whose receptaculum acts as ingesting gland, the bursa copulatrix seems to combine the functions of a spermreceiving and sperm-storing organ (Fretter 1941, f. 6 d). 
Haller (1905, t. 27, f. 6) did not see the receptaculum of $\mathbf{O}$. peruviana and observed the bursa only in part. As be found the structure of the "uterus gland" consistent with the "uterus" (capsule gland) of other prosobranchs, he evidently had sectioned the bursal vesicle, not the bursal canal. This provided, the bursal vesicle of $\mathbf{O}$. peruviana seems in certain stages to assume the same position as in our $\mathbf{O}$. sayana.

\section{Lintricula, male}

The testis (Fig. 51, t) extends from the apex to the end of the body whorl. Atypical sperms were not seen, neither in the testis, seminal vesicle and male duct nor in the bursa copulatrix and in the receptaculum seminis. The coiled testicular duct (ns) functions as vesicula seminalis; it is full of sperm. The ciliated renal spermiduct is straight and approached to the pericardium whose blind ending diverticulum (g) attains the ectal end of the renal spermiduct as in Oliva sayana.

The pallial spermiduct ( $\mathrm{sa}$ ) is muscular and densely ciliated. As in the preceding olivids it begins with a $3 \mathrm{~mm}$. long, dilated pouch (so) which communicates with the mantle cavity. It receives the renal spermiduct $0,7 \mathrm{~mm}$. to the right of its proximal end. The pouch is thin-walled and has few intra-epithelial red staining glands. Its cilia extend on to the floor of the pallial cavity forming a folded area underlain by a big visceral glanglion. Acidophilous prostatic glands occur also in the epithelium of the next, tubular part of the pallial spermiduct, but become scarce farther in front and are no longer present in the part of the pallial spermiduct that passes to the penial spermiduct (Fig. 52). Both the pallial and the penial spermiduct (Fig. 53) show a suture consisting of two joined strips of epithelium which lead from the lumen of the duct to the epithelium of the mantle cavity and to that of the penis respectively. The same feature was observed in the two $\mathrm{Mu}-$ ricacea studied by Fretter (1941, p. 177-178).

The course of the pallial spermiduct is straight and continues straight through the penis. The outer opening lies subterminally. The penis is dorso-ventrally flattened as in the other 
examined olivids, but contrary to these it ends with a blunt, not pointed, tip. In a young male (shell: $17 \mathrm{~mm}$.) the penis is about $3 \mathrm{~mm}$. long, in a little longer snail (shell: $19 \mathrm{~mm}$.) it is $12 \mathrm{~mm}$. long, and in an adult male (shell: $45 \mathrm{~mm}$.) its length is $20 \mathrm{~mm}$. The penial epidermis bears small cilia and blue staining glands near the tip. Subepithelial glands are not developed in the penis. The muscular spermiduct without glands runs on the left side; there are blood lacunae to the right and left of the duct, while the nerves are principally on the right side.

The ancestral type of gonoducts, the open groove (Moore 1899 , p. 160-166; Johansson 1953. p. 15-17), constitutes the historical basis for all kinds of spermiducal pores (id. 1939, $\mathrm{p}$. 384). As these occur in Muricacea, Buccinacea (Fretter 1941) and the here examined Olividae, and even open spermiducal grooves are known in Adelomelon ancilla (Woodward 1900, p. 118), Harpoyoluta charcoti (Eales 1923 , p. 34), Harpa ventricosa and H. nablium (Bergh 1901, p. 618,623), one must state that this primitive feature is frequent among the highly specialized (Fretter 1941, p. 208) Stenoglossa.

The vestigial male gonopericardial duct in the present olivids is similar to that in Ocenebra erinacea (Fretter 1941, p. 175); one of Fretter's buccinacean species (p. 178) has only a slight trace of such a duct. Fretter (p. 175, 206) mentioned Littorina in this connection, but Linke (1933, p. 14, 3rd paragraph) stated that there are no remnants of a male gonopericardial duct in his three examined species of Littorina.

\section{Lintricula, female}

The ovary (Fig. 54, zo) extends from the apex almost to the end of the body whorl. The grown ovocytes in the ovary contain up to 30 micra big yolk granules. The ovarian oviduct (ou) runs along the columellar muscle as in the other olivids dealt with here. Its wall is thick, muscular and provided with a high unciliated epithelium. Also the following narrower renal oviduct (ro) has a high (60 micra) unciliated epithelium whose vacuolized cells resemble those of the kidney as in Oliva. The renal oviduct communicates (g) with the pericar- 
dium (re) near its ectal end. The gonopericardial duct is wide; its outer section is lined with the kidney-like epithelium of the renal oviduct. Its inner section is continuous with the low pericardial epithelium. A sphincter is not developed, neither at the pericardial nor at the oviducal end of the gonopericardial duct. The angle between it and the oviduct makes the passage of eggs into the pericardium improbable, but the lumen of the communication would not hinder it. The terminal section between the entrance of the gonopericardial duct and the beginning of the albumen gland has thick circular muscles. The epithelium is thrown into longitudinal folds and about 40 micra high with short (4 micra) cilia.

In the albumen gland (aa) the height of the epithelial cells is 25 micra, the length of the cilia 10 micra. The epithelium is underlain by $0,4 \mathrm{~mm}$. long clusters of glands staining light violet and dark blue. The slit-like lumen of the albumen gland is straight from the inner to the outer end and is continued into the likewise broad lumen of the capsule gland (c). At the junction of the two glands a cylindrical muscular duct (w) originates and runs along the furrow between albumen and capsule glands. It enters an ingesting gland (rn) located dorsally over the glands of the pallial oviduct. The duct of the ingesting gland contains sperms attached to the wall with their heads and functions as recepetaculum seminis as in the Stenoglossa studied by Fretter.

Also the ingesting gland (Fig. 55) is very similar. It is a brown organ composed of ramified tubules with many amoebocytes and loose connective tissue between them. In a young female the epithelium contains only red granular secretion. In the adult female the 80-100 micra high cells lodge brown masses near their bases. Their free edges engulf tufts of sperm and are detached from the cell bodies by constriction together with their contents. Probably part of the sperm is actually digested and transformed into the brown granular masses. Amoebocytes enter the basal portions of the ingesting cells. As in two of Fretter's species (1941, p. 189, 192), also in Lintricula yolk granules evidently proceeding from disintegrated eggs occur in 
the ingesting gland. Dorsally tubules of the right renal lobe enter the connective tissue of the ingesting gland.

The capsule gland (c) is a massive organ, hard to be sectioned, which forms 3-4 folded lobes. These stain differently in their various parts. Specially the glands of the dorsal and those of the ventral wall have secretion of different colourability, and in between a third type occurs (Fretter 1941, p. 184). A broad gland-free ventral zone of the capsule gland might correspond to the sperm channel but is not limited by folds. The location of the receptaculum seminis and the bursa copulatrix makes it improbable that the spermatozoa of Lintricula pass through the capsule gland.

At the junction of albumen and capsule glands a $0,4 \mathrm{~mm}$. wide muscular ciliated canal (b) goes to the ventral side. This is the bursal canal which enlarges into the copulatory bursa. (cc), a curved vesicle situated under the antero-ventral wall of the capsule gland. For the intromission of the penis the bursal canal must be somewhat dislocated, or it receives only the tip of the penis, and the sperms move to the vesicle assisted by the beat of the cilia of the duct. The $0,12-0,14 \mathrm{~mm}$. high epithelium of the bursa is ciliated. The spermatozoa lie unorientated in the bursa, frequently in groups which appear to have originated from one spermatogonium each. The size of these groups corresponds to the portions incorporated by the epithelial cells of the ingesting gland. There is no prostatic secretion in the bursa in accordance with the scarcity of such secretion in the spermiduct.

A short vagina unites the mantle cavity with the point where the glands of the pallial oviduct meet and where the ducts of bursa and ingesting gland begin. Histologically the vagina belongs to the mantle cavity; it forms a pouch which corresponds to a vestibule. The female aperture (eo) lies level with the anus, but far to the left of the mouth of the pallial cavity, in the same position as the opening of the pallial spermiduct. Hence its location differs considerably from that of other Stenoglossa and resembles that of Johansson's hypothetical stage 5 (1942, p. 9) with the difference that there is no 
anterior opening in Lintricula. The egg capsules will probably be directed through the mantle cavity by the exhalant pallial current as are sperm and ova in archaeogastropods (Fretter 1946, p. 334). But as a complete pallial oviduct is developed in Lintricula, the posterior position of the female aperture cannot be considered as an ancient character. It is the consequence of a rotation of the capsule gland which entrains the bursa.

The homology of the ingesting gland with the receptaculum seminis of the mesogastropods (Fretter 1941, p. 206) and the other olivids dealt with here is, in our opinion, certain. In Lintricula part of the organ, viz. its ectal duct $(w)$, is a receptaculum, and only the ental tubules ( $r n$ ) have acquired a new function. To Fretter's examples (p. 204) of sperm digestion in other animals than molluscs Cernosvitov's four papers may be added (Zool. Jahrb. Anat. v. 52, 54, 55).

\section{Olivancillaria, female}

O. brasiliensis shows some differences from $\mathbf{L}$. auricularia in the female reproductive system. The terminal part of the renal oviduct between the entrance of the gonopericardial duct and the beginning of the albumen gland is only $0,15 \mathrm{~mm}$. long against about $0,5 \mathrm{~mm}$. in Lintricula. Its epithelium is 15 micra high with 5 micra long cilia. The duct of the ingesting gland runs between the complexes of the albumen and capsule glands, not in the outer furrow between them. In the sectioned specimen the duct does not lodge any sperm; it is very narrow, $50 \times 250$ micra in transverse section against $400 \times 600$ micra in Lintricula.

The spermatozoa in the lumen of the ingesting gland (Fig. 50) lie singly, not in bundles as in the copulatory bursa. Their blue heads are distinct; the pink tails disintegrate. Between the sperm detached apices of epithelial cells are plentiful, most of them containing many heads of sperms. The epithelial cells of the ingesting gland are up to 60 micra high. Their vacuoles which contain several to 20 sperms occupy the distal half of the cells. Within the vacuoles the heads are generally arranged in bundles. Basally to these vacuoles there are empty vacuoles 
and such with brown contents, farther basally lie the nuclei, and between them and the basement membrane the sockets of the cells which consist of dense homogeneous plasm. In this zone nuclei of interepithelial amcebocytes are conspicuous.

Two kinds of amoebocytes are distinguishable, smaller, 8 micra big ones with pink cytoplasma and larger ones, 12 micra in diameter, containing dark brown granules. Both types occur in the connective tissue of ingesting gland and kidney; evidently the bigger ones also enter the lumen of the ingesting gland.

The bursal epithelium is much lower (70 micra) than in Lintricula, whilst the epithelium of the bursal canal $(0,1 \mathrm{~mm}$.) and its diameter are the same in both species. An area of subepidermal blue staining glands is located to the left of the female aperture both in Olivancillaria and Lintricula. In the former its diameter is twice $(1 \mathrm{~mm}$ ) that of the latter $(0,5$ $\mathrm{mm}$.), and the glands are $0,3 \mathrm{~mm}$. long against 30 micra in Lintricula. The heads of the sperms of Olivancillaria are 12 micra long and half as thick as the 6 micra long ones of Lintricula.

In the studied female of Olivancillaria a functioning receptaculum seminis is wanting. The outer opening of the bursal canal immediately opposite to the junction of albumen and capsule glands enables the sperm to fertilize the ova when they pass from the albumen to the capsule gland. Hence storage of sperm in a proximal oviducal appendage is unnecessary.

\section{RENAL ORGAN}

Perrier's description of the kidney of Oliva (1889, p. 24649) quoted by Simroth (1902, p. 569-70) is better than Haller's (1905, p. 661) and Küttler's (1913, p. 53-54) whose material was not sufficiently preserved. In our olivids the excretory organ is a dorso-ventrally flattened, simple not lobed, sac which tapers towards the left and lies at the posterior end of the mantle cavity. The anterior part of the kidney belongs to the roof of the pallial cavity and bears the slit-like renal aperture $(x)$ on its ventral wall. Beside and to the left of this external opening of the kidney is localized the reno-pericardial aperture (y) which is smaller than the external opening. The posterior extra- 
-pallial part of the kidney is situated in the hind border of the body whorl. On the right side the renal organ lies between the integument and the pallial oviducal glands, on the left side between digestive gland and pericardium (er). The kidney of Lintricula extends farther over the pallial complex of the oviduct than that of Olivancillaria where both organs are separated by an interspace filled with spongy tissue. In the tapering fundus of the renal sac a dorsal stripe of the wall side by side with the pericardium is thickened; this is the nephridial gland (vv).

Two different structures of the renal organ can be distinguished, folds (Fig. 56, zc) and villosities ( $\mathrm{zn}$ ). In the olivids these structures do not characterize a right and a left renal lobe. This was already stated by Perrier (1889, p. 247), and we will not apply these terms. In comparison with the Naticidae, Cypraeidae and others with a bilobed kidney the folds of the Olividae correspond to the right and the villosities to the left lobe. The folds occur chiefly on the bottom of the renal sac, and the villosities only on the roof. The circulatory system shows that the folds are analogous to the principal renal system of Perrier's Pycnonephridia (Simroth 1902, p. 571-572; Cuénot 1914, p. 279-80), and the villosities to the accessory system. The nephridial gland (Fig. 60) is similar to the villous part (Fig. 57) and can hardly be separated from it in sections of Olivella. Also in young specimens of Lintricula both organs are alike. The folded part at the bottom covers the rectum (i) and its accompanying blood sinus. In Oliva the folded part is brown and the villous part white. Lintricula and Olivancillaria show the same difference less distinctly. In Olivella both parts are white.

The folds extend from the bottom to the roof in the right major part of the renal sac (Fig. 58). Their epithelium consists of acidophilous cells 3-5 times as high as their nuclei (Fig. 59). Most of these cells bear a striped cuticle ("plateau strié" Cuénot, 1. c.; "Bürstensaum"), some of them are ciliated. Scattered blue staining gland cells lie in the epithelium of the folds in Lintricula and Olivancillaria. The cells on the combs 
of the folds in Olivancillaria detach their apices (Fig. 62) as the merocrine cells of the ingesting gland (cf. also Ankel 1936. p. 114). The conncctive tissue of the folds is most developed in Oliva where it contains much brown pigment. The connective tissue of Lintricula is less developed, and in Olivella it is scarce. Therefore the branching of the epithelial tubes is most clearly visible in Olivella (Fig. 56) where the ramification is less complicated than in our bigger olivids.

In Oliva the whole bottom of the left minor part of the kidney contains folds, but here they do not extend to the roof. On the latter the villosities are developed along the vessels. In front the villosities pass on to the nephridial gland. Between this and the folds there is a smooth stripe, the roof of the pallial cavity, which contains the reno-pericardial (y) and the outer renal $(x)$ apertures. The posterior wall of the renal sac between folds and villosities is also smooth and apposed to the digestive gland. In Lintricula (Fig. 61) this smooth area is more extense, because the folds occupy only two thirds of the bottom. The epithelium of the villosities is quite low (Fig. 57 ), an the nuclei bulge the cells. Small blue staining glands lie between the epithelial cells. The richly developed connective tissue with amoebocytes and blood lacunae contains acidophilous protein crystalloids (Cuénot 1914, p. 281), plentiful in adults and few in young snails.

The nephridial gland (vv), as we summarily call nephridial and blood glands (Ankel 1936, p. 116) together, has the structure known of Buccinum (Dakin 1912, p. 87) and other prosobranchs. It consists of ramified epithelial tubes, outgrowths of the renal wall, which penetrate into a spongy connective tissue and are fastened by muscles. The epithelium is low as that of the villosities and ciliated; the connective tissue contains many blood lacunae and amoebocytes.

The following description of the circulation in the kidney refers mainly to Olivella (Fig. 56), sections of which comprise the entire topography. The strongly muscular afferent renal vessel (uz) emerges from the abdominal blood sinus (oc), gives off vessels to the folds at the bottom of the kidney and 
continues through the renal cavity (h) to the roof. Its ascending course is contained in the innermost of the folds which extend to the roof. Here the afferent vessel ramifies and supplies the villosities $(\mathrm{zn})$ which are disposed along its branches. The blood from the folds is collected in peripheral coalescing lacunae which communicate with the afferent branchial sinus. The blood from the villosities passes into the nephridial gland, and on the right side the sinus of the latter opens into the auricle (au) .

Haller's pericardial gland of Oliva $(1905$, t. 27 , f. 7) is, as already Küttler had observed (1913, p. 534), the gonadial duct visible through the pericardium.

\section{SYSTEMATIC DISCUSSION}

Authoritative malacologists agree to derive the Stenoglossa from the taenioglossan Doliacea (Thiele 1935, p. 1095; Graham 1941, p. 15-16; Risbec 1955, p. 71), perhaps from the Cassididae (Graham, p. 17). Two stenoglossan superfamilies, the Muricacea and the Buccinacea, are separated by differences in radula, central nervous system, foot and anterior gut (Thiele 1931, p. 287, 301; Graharn 1941). Graham observed that in the Muricacea the effect of torsion is shown anterior to the nerve ring, whilst in the Buccinacea it is the posterior half of the mid-oesophagus in which the rotation occurs. Hence the two superfamilies represent parallel lines of evolution and cannot be derived one from the other (l. c., p. 17).

In Thiele's system the rest of the Stenoglossa constitutes. the superfamily Volutacea. It is indistinctly characterized, because its most important character, the lack of lateral radular plates, develops gradually by thinning (Harpidae) and disappearing in most, not all, genera of the family Volutidae. This process is not correlated with the concentration of the central nervous system. The latter is most advanced in the Olividae with the radular formula 1-2.1.1-2, and in the Marginellidae with 0.1 .0 . In the present state of knowledge the Volutacea are distinguished from the two other stenoglossan su- 
perfamilies only by their columellar folds, and even these are sometimes missing.

One can understand that Olsson (1956, p. 168) tries to dissolve the Volutacea establishing an own superfamily, Olivacea, for the Olividae, due to the sharp separation of the propodium. The three "stirpes" of the mesogastropods in Thiele with a single family each (Valvatidae, Naticidae, Cypraeidae) have more significant and more numerous disjunctive characters than the Olivacea as defined by Olsson. It is possible with Bergh (1901, p. 610) to join the Harpidae with the Olividae in one and the same superfamily with the diagnosis: Foot large, divided into propodium and metapodium by lateral incisions or a complete transverse furrow. Evolutionally the paleocene harpids can be traced from the upper cretacean olivids, provided the general stenoglossan trend to reduce the lateral plates of the radula and suppress the accessory pharyngeal and oesophageal glands. This suppression occurs also within the olivids (Olivella).

Thiele $(1935$, p. 1095) derived the Olividae from the $\mathrm{Mu}-$ ricidae due to radular plates, accessory salivary glands, and anal gland. The last character however does not weigh phylogenetically, as Thiele (p. 1051) said. Anal glands occur sporadically among meso and neogastropods (Simroth 1901-02, p. 535, 548). It is improbable that they are remnants of a right kidney (ibid., p. 590) though Fretter (1946a, p. 128-130) proved their excretory function in some muricaceans. Olivella lacks this gland, and in Oliva sayana and Lintricula it is so small that it could be verified only in sections. Secondary salivary glands, paired with unpaired duct, or unpaired on their whole length, are certainly homologous organs. Risbec (1955, p. 50) goes too far back to the remote taenioglossan Naticidae, when he compares the precerebral part of their oesophageal gland (1956, p. 25-26) with the unpaired pharyngeal gland of the Olividae. The radular characters of the oiivids are, on the whole, more muricidan than buccinacean, but some comments are necessary. The first refers to the accessory plate of Olivella whose parallel is found among the Buccinacea 
(Nassidae). Also the peculiar rhachidian plate of Olivella with its great number of denticles occurs in several Buccinacea (Thiele 1935, p. 1044).

Finally the radula of Pseudoliva is typically buccinacean (cf. Thiele 1931, figs. 343, 383). It is significant that this relatively old genus (Moore, Lalicker, Fischer 1952, p. 318) is either classified among the Buccinacea (Olsson 1956, p. 169) or among the Olividae (Thiele). Also its foot is remarkable by its primordial propodium (Thiele 1935, p. 1095). The mighty foot of the Olividae (and Harpidae) is a buccinacean not a muricacean feature. The same applies to the concentrated central nervous system of the olivids. Muricids with concentrated ganglia occur (Simroth 1899, p. 416), but they are exceptional. Also among the Volutidae different nervous systems are found in one and the same subfamily (Harpovoluta charcoti Eales 1923, fig. 37; Voluta musica Pace 1902, t. 2, f. 3) and even within one genus (Cymbium: Thiele 1935, p. 1096). Apart from these cases which prove that the position of the supra-intestinal ganglion, contiguous with the right pleural ganglion or close to the osphradium, should not be over-rated, the high concentration of the nerve ring of the Olividae is rather buccinacean than muricacean. The anterior lobes of the pedal ganglia in nassids (Risbec 1952, p. 494) which are nearly set off as accessory ganglia resemble the propodial ganglia of olivids.

The remnants of a male gonopericardial duct in the here examined olivids are muricacean features. The same applies to the pallial spermiduct of Lintricula with the remainder of its origin from an open groove. On the other hand this duct is a closed canal without any suture in Olivella and Oliva, hence their male ducts are buccinacean.

Our discussion suggests an origin of the Olividae neither directly from the Muricacea nor from the Buccinacea, but from the common root of these. Most of the other volutacean families are too little known to settle their position. The Harpidae and the Marginellidae may descend from the Olividae, the first as an on the whole reduced group, the second as an advanced one. The Volutidae combine rather advanced radular charac- 
ters with relatively primitive nervous ones. Possibly they stand at the root of the Volutacea, together with the Olividae, forming an own line of evolution.

In a discussion of the mutual relations between the here studied olivids the various organs must be considered. Lintricula and Olivancillaria, for example, are the most perfect diggers due, to their enormous feet. Evidently advanced regarding this locomotor organ Lintricula has central ganglia less fused than Oliva, and its male duct with a suture extending from the beginning of the pallial spermiduct to the penis is the most ancestral of the forms examined here. Oliva and Lintricula have obvious muricacean features in their fore gut, viz. primary and secondary pharyngeal glands; a pyriform organ showing the effect of torsion; a mid-oesophagus with convolutions of the dorsal folds which enter the oesophageal gland and its lobes; and these lobes having a highly secretory surface. The fore gut of Olivella is, an extreme case of reduction characteristic of the Volutacea (Graham 1941, p. 17). Correlated with this reduction, these engulfers of voluminous entire prey have distensible neuroglia fibres in their central nervous system, and a gizzard-like stomach. All these features are specializations of the relatively young (Olsson 1956, p 165) genus Olivella, and its systematic separation from the Olivinae (ibid., p. 169) appears justified. Contrary to the mentioned specializations several species of Olivella, including the present, maintain the ancestral character of an operculum. Oliva appears primitive in the possession of tentacles with eyes, but its central nervous system attains the highest degree of concentration among Stenoglossa. Maybe that the hitherto anatomically unknown olivids will connect these loose and dissimilar facts in future and permit a phylogenetical arrangement of the genera which appears impossible at present.

\section{SUMMARY}

3. The olivids dealt with here live in sand. Olivella verreauxii engulfs its prey entire, chiefly Donax hanleyanus. Oliva sayana swallows particles rasped by the radula. Iintricula 
auricularia feeds in the same way, grasping and securing its prey, chiefly Donax, with the foot.

4-5. The mentioned species and Olivancillaria brasiliensis have a posterior mantle tentacle which lies in the channeled suture and a posterior mantle lobe which produces the callus and is specially strong in Olivancillaria brasiliensis. An anterior mantle tentacle occurs in Olivella and Oliva, and paired tentacles with eyes in Oliva. The resorption of the inner walls of the upper whorls known of Olivella is evident also in Oliva, Lintricula and Olivancillaria. The borders of the siphon of the two latter are beset with branched papillae which bear sensory cells. Their big foot does not enter into the shell completely. Also the posterior mantle tentacle of Olivella frequently remains outside the shell, though $\mathbf{O}$. verreauxii is operculate. The various mantle appendages are similar to one another and alike in the examined species.

6. Glands and clusters of sensory cells lie under the epidermis of the anterior border of the propodium in the here studied species. The sensory cells are connected with a propodial nerve net. The posterior pedal gland associated with the transverse ventral furrow between pro and metapodium is concentrated in Olivella and accompanies the furrow in Oliva and Lintricula. The ventral pedal gland of the females is independent in Olivella and Oliva, whilst it is only a differentiated part of a glandular metapodial groove developed in both sexes of Lintricula.

7. The central nervous system of Olivella shows distinct separation of the ganglia, even short pedal-propodial connectives are developed Neuroglia fibres accompany all central connections. They make it possible that together with the oesophagus the nerve ring can be distended when the snail swallows entire bivalves. The ganglia of Oliva are only separated by superficial constrictions; their nerve cells touch over the quite short connectives. This rigid collar allows only for feeding on rasped particles, small animals, or juice of meat. The nerve collar in Lintricula is more concentrated than in Olivella 
and less than in Oliva. Neuroglia fibres are specially developed between the secondary propodial ganglia. The extensile and contractile propodium is the most richly innervated sense organ of the present olivids, also in Oliva whose oral flaps bear tentacles with well developed eyes.

8. Olivella has only primary pharyngeal glands, no pyriform organ nor oesophageal gland. A great part of its stomach is cuticularized and acts as gizzard. The fore gut in Oliva and Lintricula is similar to that of the Muricacea (Graham 1941). The stomach of Oliva is highly differentiated; that of Lintricula and Olivancillaria is similar but without gastric shield. The anal glands of Oliva and Lintricula could be seen only in sections; that of Oliva opens beside the anus, that of Lintricula into the rectum. Olivella has no anal gland.

9. Atypical sperms of the Conus type occur in Olivella and Oliva. Lintricula has no atypical sperms. The examined olivids have remains of a male gonopericardial duct in form of a diverticulum of the pericardium ending blindly at the renal spermiduct, and in all the pallial spermiduct communicates with the mantle cavity. The origin of this duct from an open groove is indicated by its suture in Lintricula. In the latter few prostatic glands exist only in the epithelium of the pallial spermiduct. A female gonopericardial duct is present in all species. As in the Muricacea and Buccinacea (Fretter 1941) there is a proximal appendage of the pallial oviduct. It functions as receptaculum seminis in Olivella and Oliva and as ingesting gland in Olivancillaria brasiliensis and Lintricula auricularia. In the last species its duct stores orientated sperm. Voluminous copulatory bursae with long ducts are developed in Oliva, Lintricula and Olivancillaria. A vestibular pouch functions as bursa copulatrix in Olivella. The vesicular organ (internal vesicle) with long duct of Olivella stores faecal particles; it probably functions like the crystal or reiniorcement sac of the Neritidae. Capsule gland and bursa of Lintricula and Olivancillaria are rotated inwards so that the female aperture lies at the same place where in the male the pallial spermiduct opens into the mantle cavity. 
10. The simple, not lobed, renal organ comprises two structures: folds and villosities. The first correspond to the right renal lobe, the second to the left, or to the principal and accessory systems respectively. Merocrine excretion by detached apices of the epithelial cells was observed in the folds of Olivancillaria. Blood from the abdominal sinus enters folds and villosities. From the first it passes to the branchial sinus, from the latter through the nephridial gland to the auricle.

11. Muricacea and Buccinacea are parallel lines of evolution (Graham 1941). The Volutacea are a loosely united superfamily. Olsson (1956) dissolved it and established a superfamily Olivacea with one family Olividae. The Harpidae can be included in the same superfamily. The Olividae have several muricacean and some buccinacean characters, hence they cannot be derived from one of these lines, but evidently descend from its common root. Of the genera treated here Oliva has the most concentrated, central nervous system, that of Olivella is the least concentrated, and that of Lintricula is intermediate. Also the operculum of the studied Olivella is a primitive character. The alimentary tract of Olivella is the most advanced by reduction (oesophagus) and specialization (stomach). Lintricula whose foot is most highly developed has the most ancestral pallial and penial spermiduct. With Olsson (1956) we consider Oliva and Lintricula nearer related with one another than one of them with Olivella, the geologically youngest genus.

\section{SUMÁRIO}

3. As Olividae aqui estudadas vivem na areia. Olivella verreauxii engole a presa inteira, especialmente Donax hanleyanus. Oliva sayana deglüte partículas raspadas pela rádula. Olivancillaria (Lintricula) auricularia come do mesmo modo segurando a presa, principalmente Donax com o pé.

4-5. As espécies mencionadas e Olivanucillaria (Olivancillaria) brasiliensis possuem tentáculo palial posterior situado na sutura canaliculada e um lóbulo palial posterior, produtor do calo, especialmente forte em $\mathbf{O}$. brasiliensis. Tentáculo palial anterior ocorre em Olivella e Oliva; tentáculos pares com 
olhos, em Oliva. Reabsorção das paredes internas das circunvoluções superiores conhecida de Olivella é evidente também em Oliva, Lintricula e Olivancillaria. Os bordos do sifão das duas últimas são providos de papilas ramificadas que contêm células sensoriais. O grande pé delas não entra completamente na concha. Também o tentáculo palial posterior de Olivella permanece freqüentemente fora da concha apesar de ser operculada a espécie estudada. Os vários apêndices do manto são semelhantes entre si e nas espécies examinadas.

6. Glândulas e grupos de células sensoriais situam-se sob a epiderme do bordo anterior do propódio das espécies aqui tratadas. As células sensoriais ligam-se à rêde nervosa do propódio. A glândula pedal posterior, associada ao sulco transversal ventral, é concentrada em Olivella e acompanha o sulco em Oliva e Lintricula. A glândula pedal ventral das fêmeas é independente em Olivella e Oliva, ao passo que é sòmente uma parte diferenciada do sulco glandular longitudinal do metapódio presente nos dois sexos em Lintricula.

7. No sistema nervoso central de Olivella os gânglios são distintamente separados, havendo até curtos conetivos pedalpropodiais. Fibras de neuroglia acompanham tôdas as conexões centrais e possibilitam a distenção do anel nervoso juntamente com o esófago, quando o caramujo deglute biválvios inteiros. Os gânglios de Oliva são separados apenas por constrições superficiais; as células nervosas tocam-se sôbre os conetivos muito curtos. Este colar rígido permite sòmente comer partículas raspadas, pequenos animais e suco de carne. $O$ anel nervoso de Lintricula é mais concentrado que o de Olivella e menos que o de Oliva. Fibras de neuroglia são especialmente conspícuas entre os gânglios secundários do propódio. O propódio extensível e contráctil é o órgão sensorial mais ricamente inervado das Olividae presentes, também de Oliva cujos lóbulos orais têm tentáculos com olhos bem desenvolvidos.

8. Olivella possui sòmente glândulas faríngeas primárias, não porém órgão piriforme ou glândula esofágica. Grande parte do seu estômago é cuticularizada e atua como moela. O intestino de Oliva e Lintricula é semelhante ao dos Muricacea 
(Graham 1941). O estômago de Oliva é altamente diferenciado; o de Lintricula e o de Olivancillaria são semelhantes, mas desprovidos de escudo gástrico. As glândulas anais de Oliva e Lint ricula puderam ser verificadas em cortes; a de Oliva abrese ao lado do anus; a de Lintricula, no reto. Olivella não tem glândula anal.

9. Espérmios atípicos, semelhantes aos de Conus, ocorrem em Olivella e Oliva. Lintricula não tem espérmios atípicos. As Olividae examinadas têm vestígios do duto gonopericardial masculino em forma dum divertículo do pericárdio que termina cegamente no espermioduto renal. Em tôdas, o espermioduto palial comunica-se com a cavidade palial. A origem dêste duto dum sulco aberto é indicada pela sutura dêle em Linitricula. Na última há poucas glândulas prostáticas no epitélio do espermioduto palial. Duto gonopericardial feminino existe em tôdas as espécies. Apêndice proximal do oviduto palial ocorre como nos Muricacea e Buccinacea (Fretter 1941). Funciona como receptáculo seminal em Olivella e Oliva e como glândula absorvente em Olivancillaria e Lintricula. Na última, o duto da glândula armazena espérmios. Bursas copuladoras volumosas com dutos compridos existem em Oliva, Lintricula e Olivancillaria. Em Olivella, uma bolsa do vestíbulo funciona como bursa copuladora. O órgão vesicular (vesícula interna) com duto comprido de Olivella armazena partículas fecais; provàvelmente funciona como o saco de cristais ou de refôrço das Neritidae. Glândula de casulo e bursa de Lintricula e Olivancillaria são de tal modo voltadas para dentro que a abertura feminina se localiza no mesmo lugar em que o espérmioduto palial do macho se abre na cavidade do manto.

10. No órgão renal que é simples, não lobado, há duas estruturas: dobras e vilosidades. As primeiras correspondem ao lóbulo direito; as segundas ao esquerdo, ou aos sistemas primário e acessório, respectivamente. Excreção merócrina por separação dos ápices das células epiteliais foi vista nas dobras de Olivancillaria. O sangue do sẹio abdominal entra nas dobras e nas vilosidades, saindo das primeiras para a brânquia e das. segundas, através da glândula nefridial, para o átrio. 
11. Muricacea e Buccinacea são linhas evolutivas paralelas (Graham 1941). Os Volutacea constituem uma entidade frouxamente ajuntada. Olsson (1956) dissolveu-a estabelecendo a superfamília Olivacea com a família Olividae. As Harpidae poderiam ser incluídas nos Olivacea. As Olividae têm vários caracteres dos Muricacea e alguns dos Buccinacea. Por isso não podem ser derivadas de uma destas linhas, mas descendem evidentemente da raiz comum das duas. Dos gêneros aqui estudados, Oliva tem o sistema nervoso central mais concentrado; Olivella, o menos concentrado, sendo o de Lintricula intermediário. Também o opérculo da Olivella estudada é caráter primitivo. O tracto alimentar de Olivella é o mais adiantado por redução (esôfago) e especialização (estômago). Lintricula cujo pé é o mais altamente desenvolvido tem o espermiduto palial e penial mais ancestral. Com Olsson (1956) consideramos Oliva e Lintricula mais relacionadas uma com outra que uma delas com Olivella, o gênero geològicamente mais jovem.

\section{REFERENCES}

ABBOTT, R. T. 1955, American Seashells. XIV + 541 p., 40 t. New York (D. van Nostrand Company, Inc.) .

ANDREWS, E. A. 1933, The storage sac for capsule reinforcement in the Neritidae. Science (n. ser.) v. 78, n. ${ }^{\circ} 2011$, p. 39-41. Washington, D. C.

_ 1935, The egg capsules of certain Neritidae. J. Morphol. v. 57, p. $31-59,3$ t. Philadelphia, Pa.

- 1937, Certain reproductive organs in the Neritidae. J. Morphol. v. 61, n. ${ }^{\circ}$, p. 525-561, 6 t. Philadelphia, Pa.

ANKEL, W. E. 1924, Spermatozoendimorphismus und Befruchtung bei Bythinia tentaculata L. Senckenbergiana v. 6, fasc. 1-2, p. 1-12, text-figs. 1-6. Frankfurt a. M.

1929, Ueber die Bildung der Eikapseln bei Nassa-Arten. Verh. D. Zool. Ges. p. 219-230, 6 text-figs. Leipzig. (Suppl. v. 4, Zool. Anz.).

- 1930, Die atypische Spermatogenese von Janthina (Prosobranchia, Ptenoglossa). Zeitschr. Zellforsch. \& mikr. Anat. v. 11 , fasc. $3-4$, p. $491-608,61$ text-figs., t. 6 . Berlin . 
1947, Ueber den offenen Uterus bei einigen Monotocardiern ohne Kopulationsorgane. Zool. Bidr. v. 25, p. 102-110, 11 textfigs. Uppsala.

- 1953, On the genital organs of some mesogastropods... Contributions to the phylogeny of the pallial gonoducts of the Prosobranchia. Zool. Bidr. v. 30, p. 1-23, 10 text-figs., ;t. 1. Uppsala .

- 1957, Notes on the littorinacean and stenoglossan genital organs, and a comparison with the Rissoacea. Zool. Bidr. v. 32 , p. 81-91, 8 text-figs. Uppsala.

JOHNSON, C. W. 1911, Some notes on the Olividae - 3. Nautilus v. 24, p. 121-124. Philadelphia, Pa.

- 1934, List of marine Mollusca of the Atlantic coast from Labrador to Texas. Proc. Boston Soc. Nat. Hist. v. 40 (193435), p. 1-204. Boston.

KRULL, H. 1935, Anatomische Untersuchungen an einheimischen Prosobranchiern und Beiträge zur Phylogenie der Gastropoden. Zool. Jahrb. Anat. v. 60, p. 399-464, 22 text-figs. Jena.

KƯTTLER, A. 1913, Die Anatomie von Oliva peruviana Lamarck. Zool. Jahrb. Suppl. v. 13 (Fauna Chil. v. 4), p. 477-544, 51 text-figs. Jena.

LANGE DE MORRETES, F. 1949, Ensaio de catálogo dos Moluscos do Brasil. Arq. Mus. Paranaense v. 7, p. 5-216. Curitiba (Brazil).

IJINKE, O. 1933, Morphologie und Physiologie des Genitalapparates der Nordseelittorinen. Wiss. Meeresunters. N. F. Abtlg. Helgol. v. 19, fasc. 2 , n. ${ }^{\circ}$, p. 1-60, t. 1-8. Kiel \& Leipzig.

MILLOTT, N. 1937, On the morphology of the alimentary canal, process of feeding, and physiology of digestion of the nudibranch mollusc Jorunna tomentosa (Cuvier). Phil. Transact. R. Soc. Lond. ser. B. - Biol. Sci. n. ${ }^{\circ} 551$, v. 228, p. 173-218. London.

MOORE, J. E. S. 1899, Molluscs of the Great African Lakes. III. Tanganyikia rufofilosa and the genus Spekia. Qu. Journ. micr. Sci. n. ser. v. 42, n. $^{\circ} 166$, p. $155-185$, t. 14-19. London.

MOORE, R. C., LALICKER, C. G. and FISCHER, A. G., 1952, Invertebrate Fossils. 766 pp. McGraw Hill Book Co., New 'York.

MORTON, J. E. 1953, The functions of the gastropod stomach. Pr. Linn. Soc., session 164 (1951-52), part 3, p. 240-246, 3 textfigs. London.

1958, Torsion and the adult snail; a re-evaluation. Proc. Malacol. Soc. v. 33, part 1, p. 2-10, 4 text-figs. London. 
EALES, N. B. 1923, Mollusca. Part V. Anatomy of Gastropoda (except the Nudibranchia). Brit. Antarct. ("Terra Nova") Exped. 1910. Zool. v. 7, n. ${ }^{\circ} 1$,p. 1-45, 42 text-figs. London.

FISCHER, P. 1881, Note sur le genre Olivella. Journ. Conchyliol. v. 29, p. 31-35. Paris.

FiSCHER, P.-H. 1950, Vie et Moeurs des Mollusques. Bibl. Scient., 312 p., 180 text-figs. Paris (Payot, 106, Boulevard SaintGermain) .

FRETTER, V. 1939, The structure and function of the alimentary canal of some tectibranch molluscs, with a note on excretion. Transact. R. Soc. Edinb, v. 59, part 3 (n. $\left.{ }^{\circ} 22\right)$, p. 599646, 22 text-figs. Edinburgh.

- 1941, The genital ducts of some British stenoglossan prosobranchs. Journ. mar. biol. assoc. Unit. Kingd. v. 25, n. ${ }^{\circ}$, p. 173-211, 6 text-figs. Cambridge.

- 1946, The genital ducts of Theodoxus, Lamellaria and Trivia, and a discussion on their evolution in the prosobranchs. Journ. mar. biol. assoc. Unit. Kingd. v. 26 (1947), n. ${ }^{\circ} 3$ (1946), p. 312-351, 7 text-figs. Cambridge.

- 1946a, The pedal sucker and anal gland of some British Stenoglossa. Proc. Malacol. Soc. v. 27, part 3, p. 126-130, 2 textfigs. London.

- 1948, The structure and life history of some minute prosobranchs of rock pools, etc. Journ. mar. biol. assoc. Unit. Kingd. v. 27, p. 597-632, 6 text-figs., t. 4. Cambridge.

- 1951, Observations on the life history and functional morphology of Cerithiopsis tuberculata (Montagu) and Triphora perversa (L.). Ibid. v. 29, p. 567-586, 6 text-figs. Cambridge.

1956, The anatomy of the prosobranch Circulus striatus (Philippi) and a review of its systematic position. Pr. Zool. Soc. London v. 126, part 3, p. 369-381, 5 text-figs. London.

FRETTER, V. \& GRAHAM, A. 1954, Observations on the opisthobranch mollusc Acteon tornatilis (L.). Journ. mar. biol. assoc. Unit. Kingd. v. 33, p. 565-585, 9 text-figs. Cambridge.

GERLACH, S. A. 1957, Die Nematodenfauna des Sandstrandes an der Küste von Mittelbrasilien. Mitteil. Zool. Mus. Berlin v. 33, fasc. 2, p. 411-459, 16 text-figs., 4 t. Berlin.

GIESE, M. 1913, Gonopericardialgang und Umbildung der Geschlechtswege im Zusammenhang mit Protandrie bei Calyptraea sinensis. Zool. Anz. v. 42, p. 433-440. Leipzig. 
- 1915, Der Genitalapparat von Calyptraea sinensis Lin., Crepidula unguiformis Lam. und Capulus hungaricus Lam. Zeitschr. wiss. Zool. v. 114, p. 169-231, t. 5-8. Leipzig.

GOFFERJE', C. N. 1950, Contribuição à zoogeografia da malacofauna do litoral do Estado do Paraná. Arq. Mus. Paranaense v. 8, p. 221-282, t. 31-35. Curitiba (Brazil).

GRAHAM, A. 1938, The structure and function of the alimentary canal of aeolid molluses, etc. Transact. R. Soc. Edinb. v. 59, part 2, n. ${ }^{\circ}$ 9, p. 267-307, 14 text-figs. Edinburgh.

- 1939, On the structure of the alimentary canal of style-bearing prosobranchs. Pr. Zool. Soc. London, Ser. B, v. 109, p. 75-112, 10 text-figs, London.

GRAHAM, A. 1941, The oesophagus of the stenoglossan prosolbranchs. Pr. R. Soc. Edinb. v. 61, part 1, p. 1-23, 5 text-figs. Edinburgh \& London.

- 1949, The molluscan stomach. Transact. R. Soc. Fdinb. v. 61 , pt. 3 (n. ${ }^{\circ} 27$ ), p. 737-778, 24 figs. Edinburgh.

— 1955, Molluscan Diets. Proc. Malacol. Soc. v. 31, p. 144-J59. London.

- 1957, The molluscan skin with special reference to prosobranchs. Proc. Malacol. Soc. v. 32, part 4, p. 135-144. London.

HALLER, B. 1905, Ueber Oliva peruviana Lamarck. Jen. Zeitschr. Naturw. v. 40, p. 647-664, t. 27. Jena.

HIRSCH, G. Chr. 1915, Die Ernährungsbiologie fleischfressender Gastropoden. I. Teil. Zool. Jahrb. Allg. Zool. Physiol. v. 35, fasc. 4, p. 357-504, 44 text-figs. Jena.

FULBERT, G. S. F. B. \& YONGE, C. M. 1937, A possible function of the osphradium in the Gastropoda. Nature v. 139 , n. ${ }^{\circ}$ 3524, p. 840-841. London.

IHERING, H. v. 1897, A Ilha de São Sebastião. Rev. Mus. Paulista v. 2, p. 129-171. São Paulo.

JAKUBSKI, A. 1913, Studien über das Gliagewebe der Mollusken, I. Teil. Lamellibranchiata und Gastropoda. Zeitschr. wiss. Zool. v. 104, p. 81-118, t. 3-5. Leipzig.

JOHANSSON, J. 1939, Anatomische Studien über die Gastropodenfamilien Rissnidae und Littorinidae. Zool. Bidr. v. 18 (1938$40)$, p. 287-396, t. 1-11. Uppsala.

- 1942, Von diaulen Geschlechtsapparaten bei den Prosobranchiern. Ark. Znol. v. 34 A, n. ${ }^{\circ} 12$, p. 1-10, 8 text-figs., t. 1. Stockholm. 
-_ 1936, Prosobranchia. Grimpe \& V Vagler, Tierw. Nord- \& Ostsee, part IX b 1, 240 p., 222 text-figs. Leipzig (Akadem. Verlagsges.).

- 1938, Erwerb und Aufnahme der Nahrung der Gastropoden. Zool. Anz. Suppl. v. 11 (Verh. D. Zool. Ges. 1938), p. 223295, 68 text-figs. Leipzig.

BALES, BLENN R. 1946, The Bar. Nautilus v. 59, n.o 3, p. 73-76. Philadelphia, $\mathrm{Pa}$.

BERGH, R. 1896, Beiträge zur Kenntnis der Coniden. Nov. Act. Leopold. v. 65, n. ${ }^{\circ}$, p. $67-214$, t. 1-13. Halle a. S.

— 1901, Beitrag zur Kenntnis der Gattung Harpa. Zool. Jahrb. Anat. v. 14, p. 609-629, t. 47 . Jena.

BERNARD, F. 1890, Recherches sur les organs palléaux des Gastéropodes prosobranches. Ańn. Sci. nat. Zool. sér. 7, v. 9, p. 89-404, t. 6-13. Paris.

EOURNE, G. C. 1908, Contributions to the morphology of the group Neritacea of aspidobranch gastropods. Part 1. The Neritidae. Proc. Zool. Soc. London 1908, p. 810-887, t. 46-66. London.

- 1911, Id. Part 2. The Helicinidae. Ibid. 1911, p. 759-809, t. 30-42. London.

EOUVIER, B. L. 1887, Système nerveux, morphologie générale et classification des Gastéropodes prosobranches. Ann. Sci. nat. Zool. sér. 7, v. 3, p. 1-510, t. 1-19. Paris.

CARCELlES, A. 1944, Catalogo de los moluscos marinos de Puerto Quequén. Rev. Mus. La Plata (n. ser.), Zool. v. 3, p. 233309, t. 1-15. La Plata.

CLARI, W. C. 1958 , Notes on the mantle cavity: of some Trochid and Turbinid Gastropoda. Proc. Malacol. Soc. v. 33, part 2, p. 5764, 7 text-figs. London.

CROSSE, H. \& FISCHER, P. 1882, Note complémentaire sur la résorption des parois internes chez les Olivella. Journ. Conchyliol. v. 30 , p. 181-183, t. 8, f. 12, 15-16. Paris.

CUÉNOT, L. 1914, Les organes phagocytaires des Mollusques. Arch. Zool. expér. génér. v. 54 (1914-15), fasc. 9 (6. VII. 1914), p. 267-305, t. 10-13. Paris.

DAKIN, W. J. 1912, Buccinum (The Whelk). L. M. B. C. Mem. XX, VIII + 115 p., 8 t. London.

DALL, W. H. 1889, Report on the Mollusca ("Blake") II. Gastropoda and Scaphopoda. Bull. Mus. Comp. Zool. v. 18, p. 1-492, t. 10-40. Cambridge, Mass. 
OLSSON, A. A. 1956, Studies on the genus Olivella. Proc. Acad. Philad. v. 108, p. 155-225, t. 8-16. Philadelphia, Pa.

ORBIGNY, A. d' 1835-1846, Voyage dans l'Amérique Méridionale v. 5, 3e partie Mollusques. Atlas 1846. Paris \& Strasbourg.

FACE, S. 1902, On the anatomy and relationships of Voluta musica, Linn.; with notes on certain other supposed members of the Volutidae. Proc. Malacol. Soc. v. 5 (1903), p. 21-31, t. 2. London.

PERRIER, R. 1889, Recherches sur l'anatomie et l'histologie des Gastéropodes prosobranches. Ann. Sci. nat. Zool. sér. 7, v. 8, p. 61-315, t. 5-13. Paris.

POWELL, A. W. B. 1951, Antarctic and Subantarctic Mollusca: Pelecypoda and Gastropoda. Discovery Reports, v. 26, p. 47-196, 130 figs., t. 5-10. Cambridge.

REEVE, A. L. 1850, Monograph of the genus Oliva. Conchologia Iconica, v. 6 (1851), 29 t. London.

ŁISBEC, J. 1928, Contribution à l'étude anatomique de quelques espèces de Mitres de la presqu'ile de Nouméa. Bull. Mus. Hist. Nat. v. 34, p. 105-112, t. 1; p. 173-180, t. 2; p. 225-227. Paris.

_ 1932, Note sur la ponte et le développement de Mollusques Gastéropodes de Nouvelle-Calédonie. Bull. Soc. Zool. France v. 57, n. ${ }^{\circ}$, p. 358-374. Paris.

RISBEC, J. 1937, Signification de la glande du calcaire des Neritina. C. R. Acad. Sci. v. 204, p. 374-376. Paris.

1942, Recherches anatomiques sur les prosobranches de la Nouvelle Calédonie (troisième partie). Ann. sci. nat. Zool. sér. 11 , v. 4 , p. 21-83, 8 t. Paris.

1952, Observations sur l'anatomie des Nassidae de NouvelleCalédonie. Bull. Soc. Zool. France v. 77, n. ${ }^{\circ}$ 5-6, p. 487-495, 11 text-figs. Paris.

- 1955, Considérations sur l'anatomie comparée et la classification des Gastéropodes Prosobranches. Journ. Conchyliol. v. 95, p. 45-82, 22 figs. Paris.

_ 1956, Étude anatomique de Naticidae de Nouvelle-Calédonie. Journ. Conchyliol. v. 96, p. 12-45, t. 1-6. Paris.

SCHAFFER, J, 1913, Ueber den feineren Bau und die Entwicklung des Knorpelgewebes, etc. IV. Teil. Zeitschr. wiss. Zool. v. 105, p. $280-347$, t. $18-19$. Leipzig.

SCHREIBER, G. 1930, Studi sul pigmento cromolipoide, l'apparato fenestrato e la respirazione di supplemento del sistema nervoso. Pubbl. Staz. Zool. Napoli, v. 10, fasc. 2, p. 151-195, t. 3-6. Roma \& Berlin. 
SIMROTH, H. 1896-1907, Gastropoda Prosobranchia. Bronn, Kl. Ordn. v. 3, 2. Abtlg., VII + 1056 p., 63 t. Leipzig (C. F. Winter).

SMITH, E. A. 1890, Mollusca in: H. N. Ridley, Notes on the Zoology of Fernando Noronha. J. Linn. Soc. Zool. v. 20 (1886-90), p. 483-503, t. 30 . London.

SOUZA LOPES, H. DE \& ALVARENGA, M. 1955, Contribuição ao conhecimento dos Moluscos da ilha Fernando de NoronhaBrasil. Bol. Inst. Oceanogr. v. 6, fasc. 1-2, p. 157-196, 3 t., 1 map. São Paulo.

IHIELE, J. 1931; 1935, Handbuch der systematischen Wieichtierkunde. VI \& V, 1154 pp., 897 text-figs. Jena (G. Fischer).

TOURAINE, J. 1952, Les glandes pédieuses des Gastéropodes Prosobranches Monotocardes. Bull. Soc. Zool. France. v. 77, p. 240241. Paris.

WEINKAUFF, H. C. 1878, Die Gattung Oliva. In: Martini \& Chemnitz, Systematisches Conchylien-Cabinet, v. 5, Abthlg. 1, 172 pp., t. A-C, 1-39. Nürnberg (Bauer \& Raspe).

hOODWARD, M. F. 1900, Note on the anatomy of Voluta ancilla (Sol.), Neptuneopsis gilchristi Sby., and Volutilithes abyssicola (Ad. \& Rve.). Proc. Malacol. Soc. v. 4 (1901), p. 117125, t. 10. London.

YONGE, C. M. 1938, Evolution of ciliary feeding in the Prosobranchia, with an account of feeding in Capulus ungaricus. Journ. mar. biol. assoc. Unit. Kingd. v. 22 (1937-38), n. ${ }^{\circ}$ (1938), p 453-468, 6 text-figs. Plymouth.

… 1947, The pallial organs in the aspidobranch Gastropoda and their evolution throughout the Mollusca. Phil. Transact. R. Soc. Lond. ser. B. Biol. Sci. n. ${ }^{\circ} 51$, v. 232, p. 443-518, 40 textfigs., t. 18. London.

\section{EXPLANATION OF LETTERS}

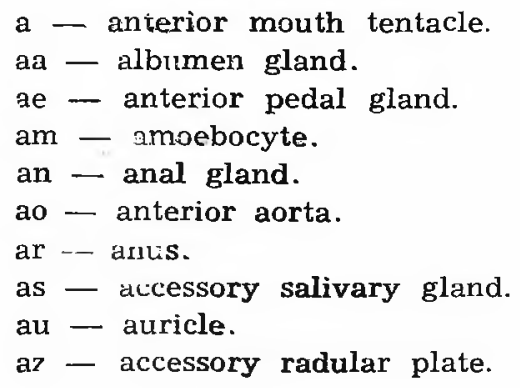

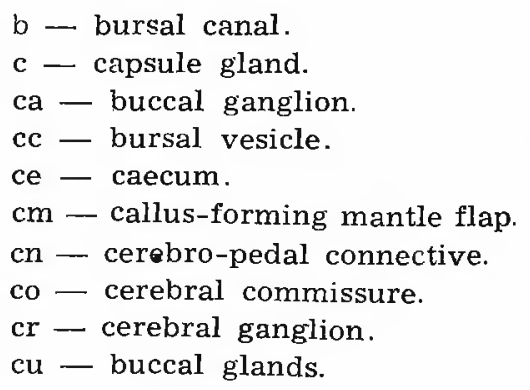


cv - columellar nerve.

cw - callus.

cz - columellar muscle.

d - ducts of digestive gland.

e - $\ddot{\mathrm{eg} g}$.

ea - left posterior visceral ganglion.

em - pedal commissure.

en - pedal ganglion.

eo - female aperture.

cr - pericardium.

ez - left zygosis.

$f$ - fold behind propodium.

$\mathrm{g}$ - gonopericardial duct or strand.

h - kidney.

$i$ - intestine.

ia - orifice of proboscis.

ie - gizzard region of stomach.

io - gland in duct of oesophageal gland.

ir - intestinal groove.

iu - propodium.

iv - internal vesicle.

$\mathrm{j}$ - stomach.

$\mathbf{k}$ - ctenidium.

1 - labial cleft.

m -. metapodium .

ma - mantle border.

mi - major typhlosole.

mo - mouth.

$\mathrm{mr}$ - middle plate of radula.

mir - minor typhlosole.

mv - mouth flaps.

mw - posterior mantle tentacle.

$\mathrm{mz}$ - muscular belt of stomach.

n - neuroglia nuclei.

ne - nerve fibres.

ni - neuroglia fibres.

no - pharynx of Leiblein.

$\mathrm{nr}$ - parapodium.

ns - vesicula seminalis.

nu -- neuroglia coat.

o - cesophagus. oa - opening of accessory salivary gland.

oc - blood lacuna.

ce - oesophageal gland.

om - oesophageal muscle ring.

, - odontoblasts.

or - operculum.

эs - longitudinal fold of stomach.

ou - ovarian duct.

ov - opening of primary salivary gland.

ow - osphradium.

$\mathrm{p}$ - proboscis.

q - lateral radular plate.

$\mathrm{r}$ - radula.

ra - posterior pedal gland.

re - peri-intestinal connective tissue.

re - posterior sorting area.

In - receptaculum seminis or ingesting gland.

ro - secondary propodial ganglia.

rs - radular support.

ru - radular cuticle.

rv - renal oviduct.

rw - right posterior visceral ganglion.

s - statocyst.

sa - pallial spermiduct.

se - propodial ganglion.

si - gastric shield.

sm - communication between spermiduct and mantle cavity.

sn - pallial-siphonal nerve

so - pouch of pallial spermiduct.

sr - sperm channel.

ss - primary salivary gland.

su - testicular duct.

$s z$ - proboscis sheath.

- testis.

te - spermiduct.

ua - pleural ganglion.

uc - gastric cuticle. 


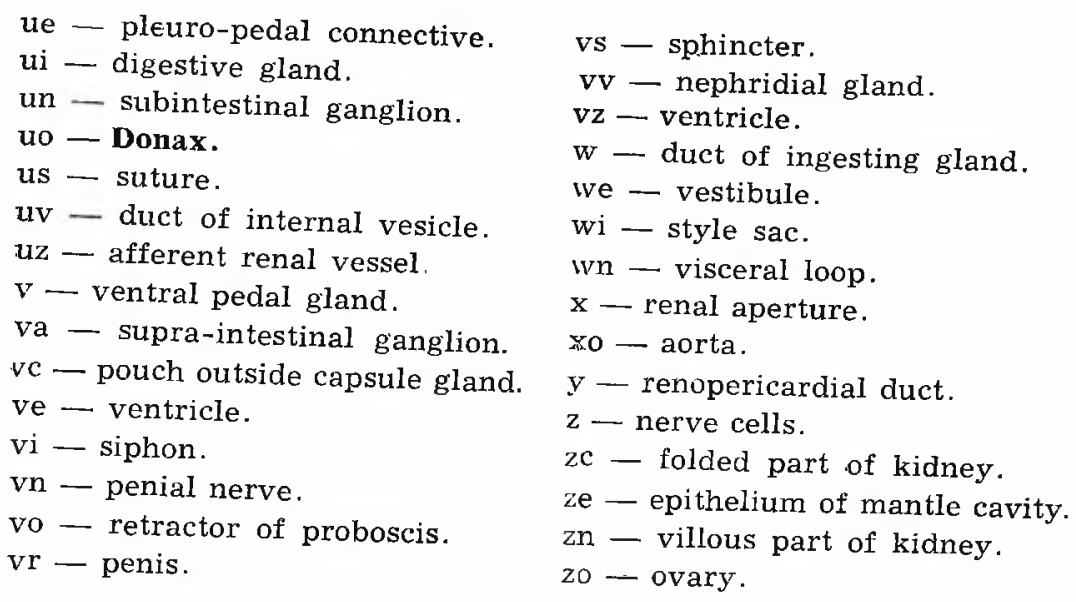


P L A T E S 


\section{PLATE 1}

Fig. 1 - Trail of Olivella.

Fig. 2 - Olivancillaria gliding.

Fig. 3 - Lintricula feeding on a clam in front of it.

Fig. 4 - Lintricula feeding on a clam held in its foot; dorsal view .

Fig. 5 - Lintricula feeding as in Fig. 4; ventral view.

Fig. 6 - Lintricula, different feeding position; ventral view.

Fig. 7 - Lintricula feeding as in Fig. 6; lateral view.

Fig. 8 - Lintricula, everted proboscis.

Fig. 9 - Lintricula, tip of siphon of preserved specimen. 
E. \& E. MARCUS - OLIVIDAE - PLATE 1
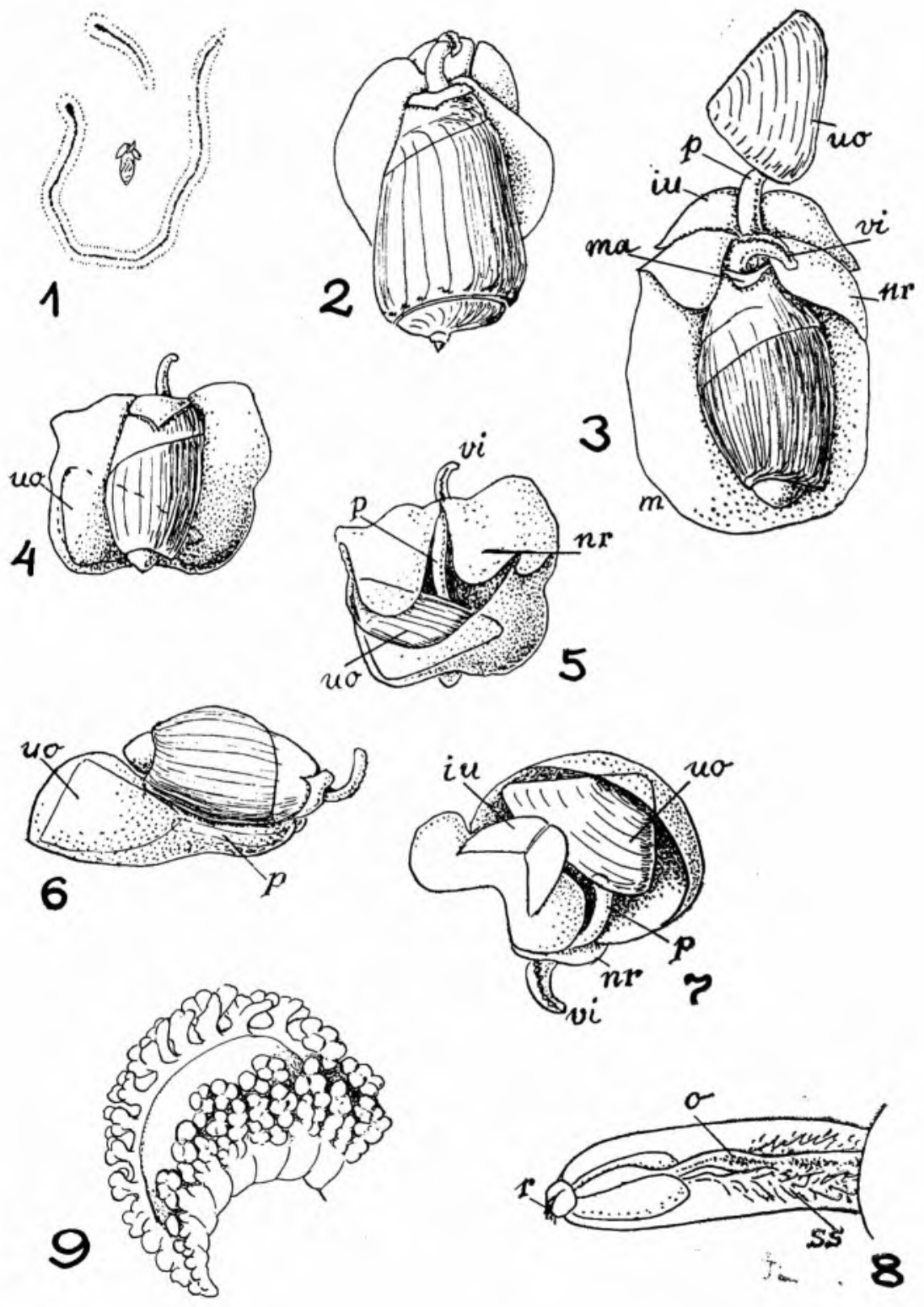


\section{PLATE 2}

Fig. 10 - Olivella, ventral view of preserved male. Fig. 11 - Olivella, ventral view of preserved female. Fig. 12 - Olivella, dorsal view of anterior part.

Fig. 13 - Olivella, diagram of anterior skin glands. Fig. 14 - Lintricula, sole of preserved male. 
E. \& E. MARCUS - OLIVIDAE - PLATE 2
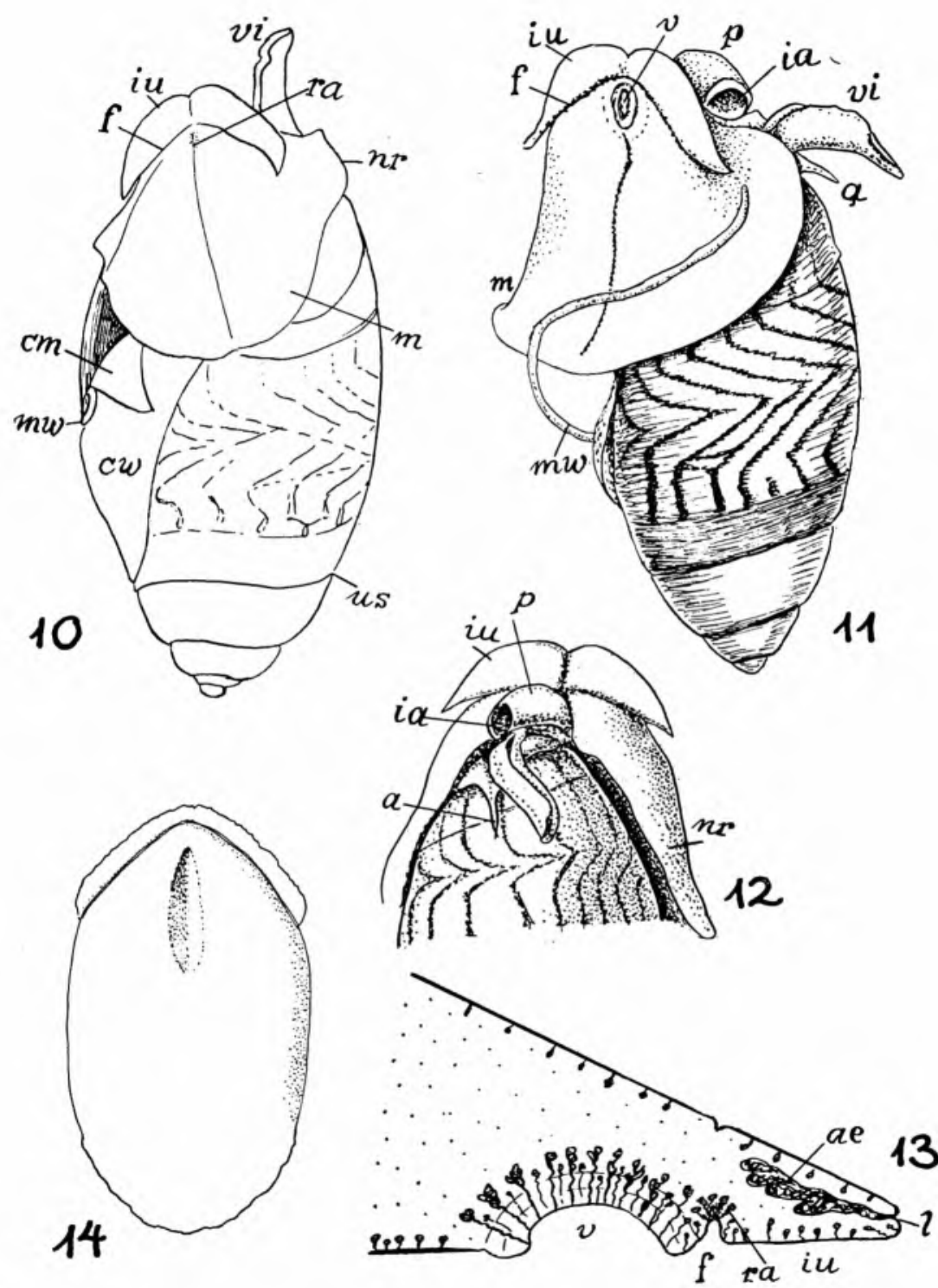


\section{PLATE 3}

Fig. 15 - Olivella, combined sagittal section of anterior region.

Fig. 16 - Oliva, transverse section of ventral pedal gland.

Fig. 17 - Olivella, longitudinal section of pleuro-pedal connective.

Fig. 18 - Olivella, transverse section of cerebro-pedal connective. 
E. \& E. MARCUS - OLIVIDAE - PLATE 3

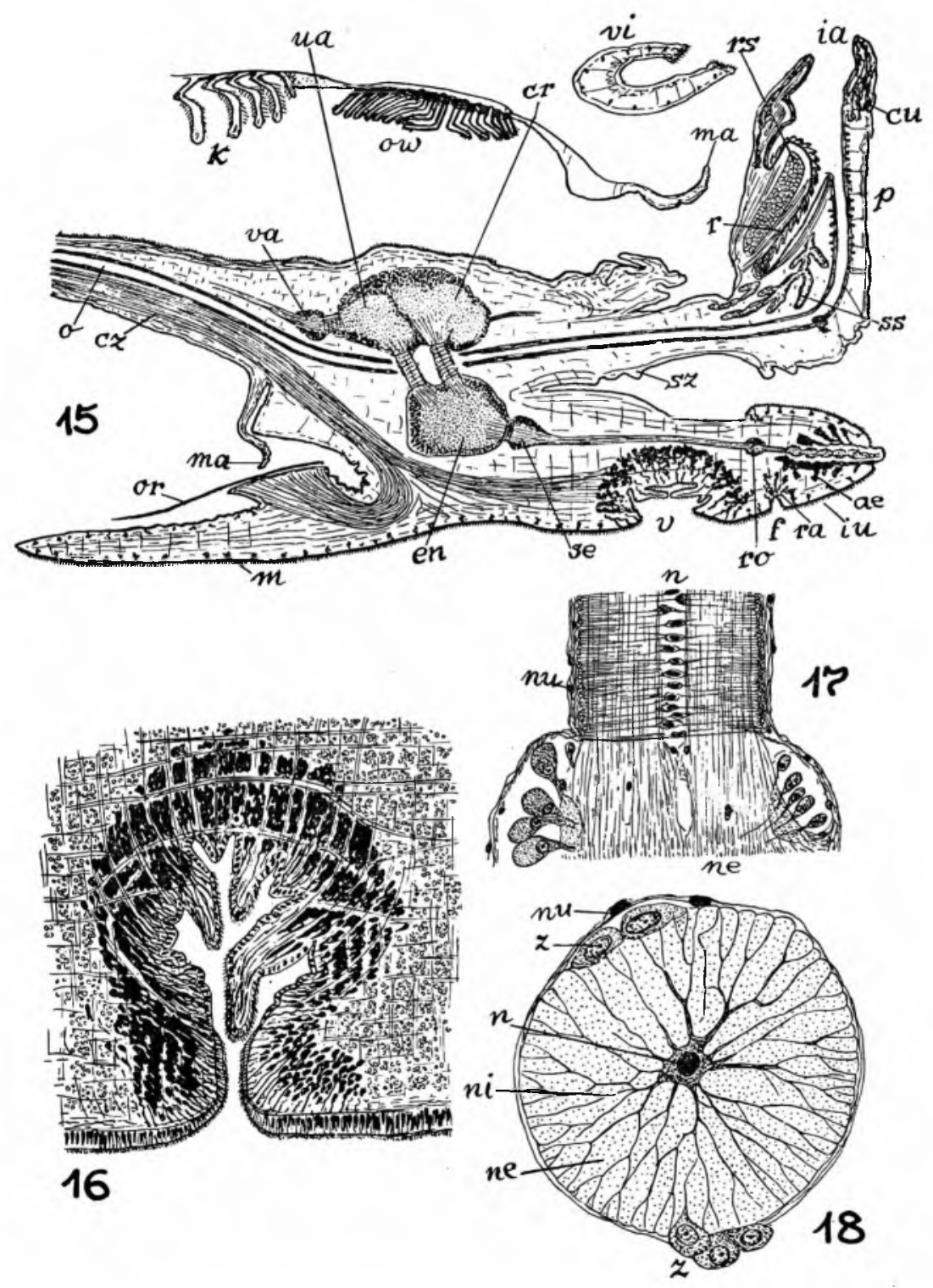


PLATE 4

Fig. 19 - Olivella, dorsal view of central nervous system.

Fig. 20 - Oliva, dorsal view of central nervous system.

Fig. 21 - Oliva, right-side view of central nervous system.

Fig. 22 - Oliva, combined transverse section of nerve ring. 
E. \& E. MARCUS - OLIVIDAE - PLATE 4

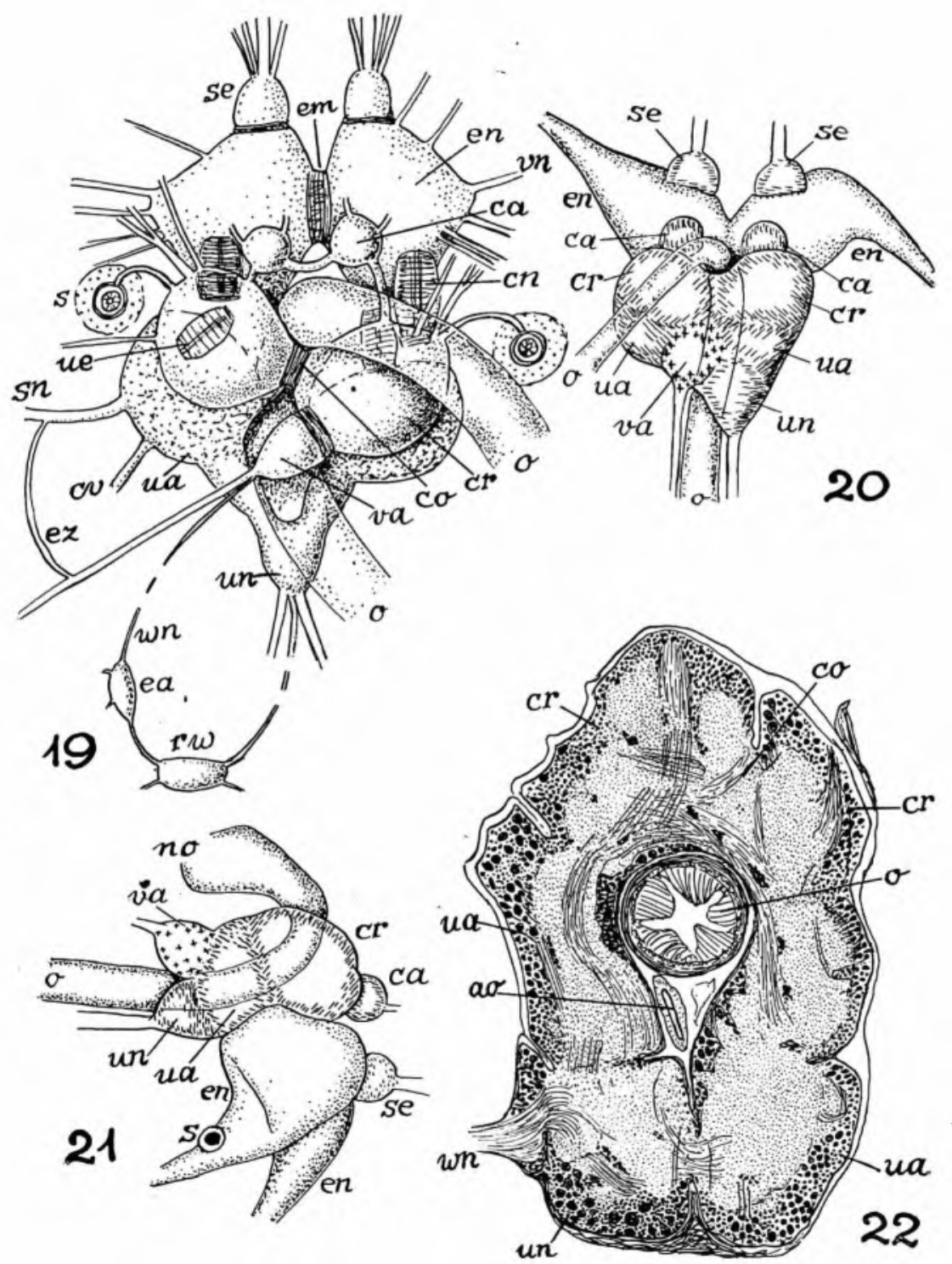




\section{PLATE 5}

Fig. 23 - Lintricula, dorsal view of central nervous system.

Fig. 24 - Lintricula, right-side view of central nervous system.

Fig. 25 - Lintricula, a sagittal section of the central nervous system.

Fig. 26 - Clivella, plates of radula.

Fig. 27 - Oliva, plates of radula.

Fig. 28 - Lintricula, plates of radula. The scale applies to Figs. 27-29.

Fig. 29 - Olivancillaria, plates of radula. 
E. \& E. MARCUS - OLIVIDAE - PLATE 5

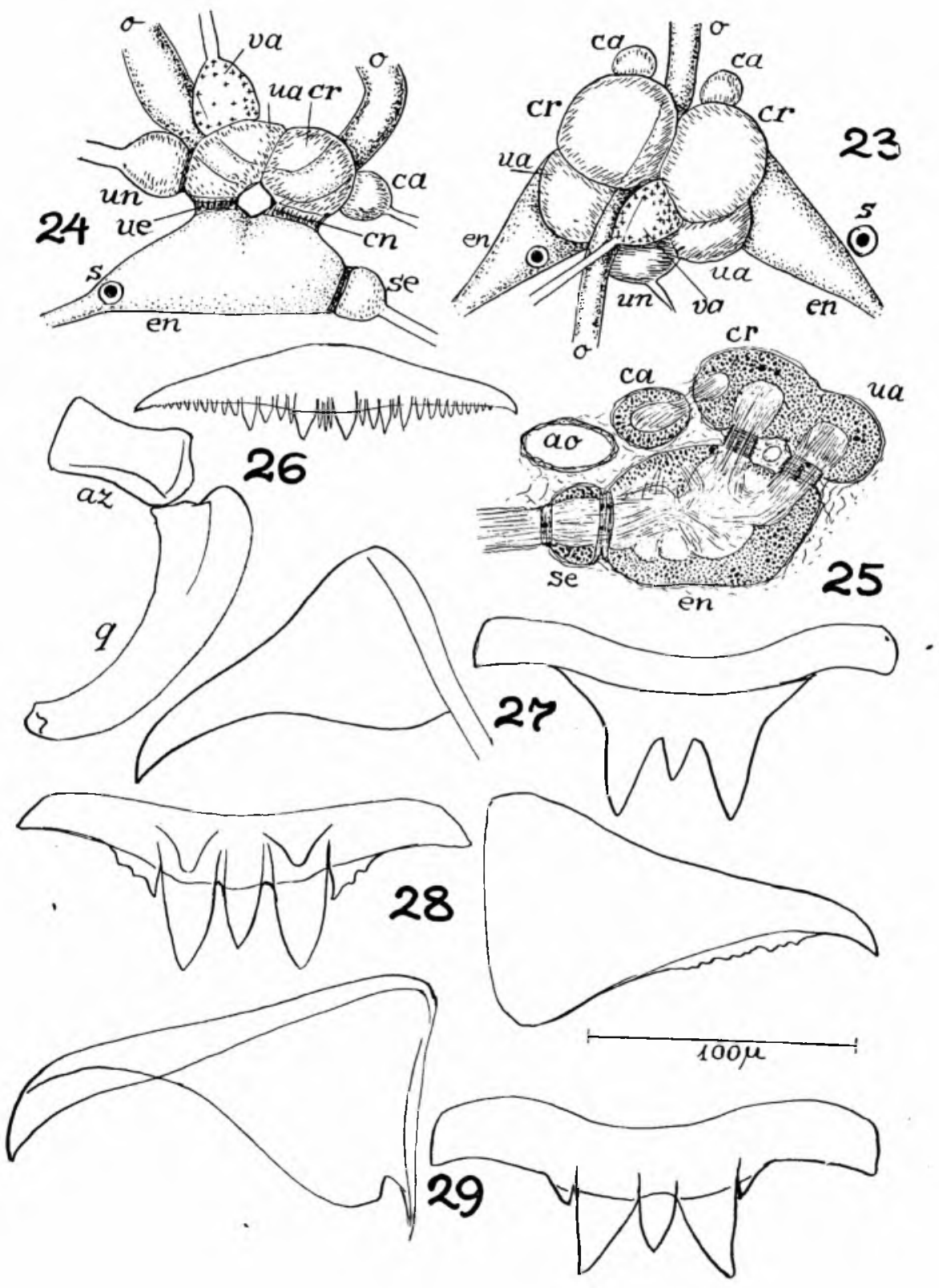




\section{PLATE 6}

Fig. 30 - Olivella, diagram of proboscis and oesophagus.

Fig. 31 - Olivella, transverse section of radula and support.

Fig. 32 - Olivella, transverse section of radular sac.

Fig. 33 - Olivella, transverse section of pre- and post-cerebral limb of oesophagus; the former with allusive pharynx of Leiblein.

Fig. 34 - Olivella, stomach.

Fig. 35 -- Olivella, transverse section of sclerosed part of stomach. 
E. \& E. MARCUS - OLIVIDAE -- PLATE 6

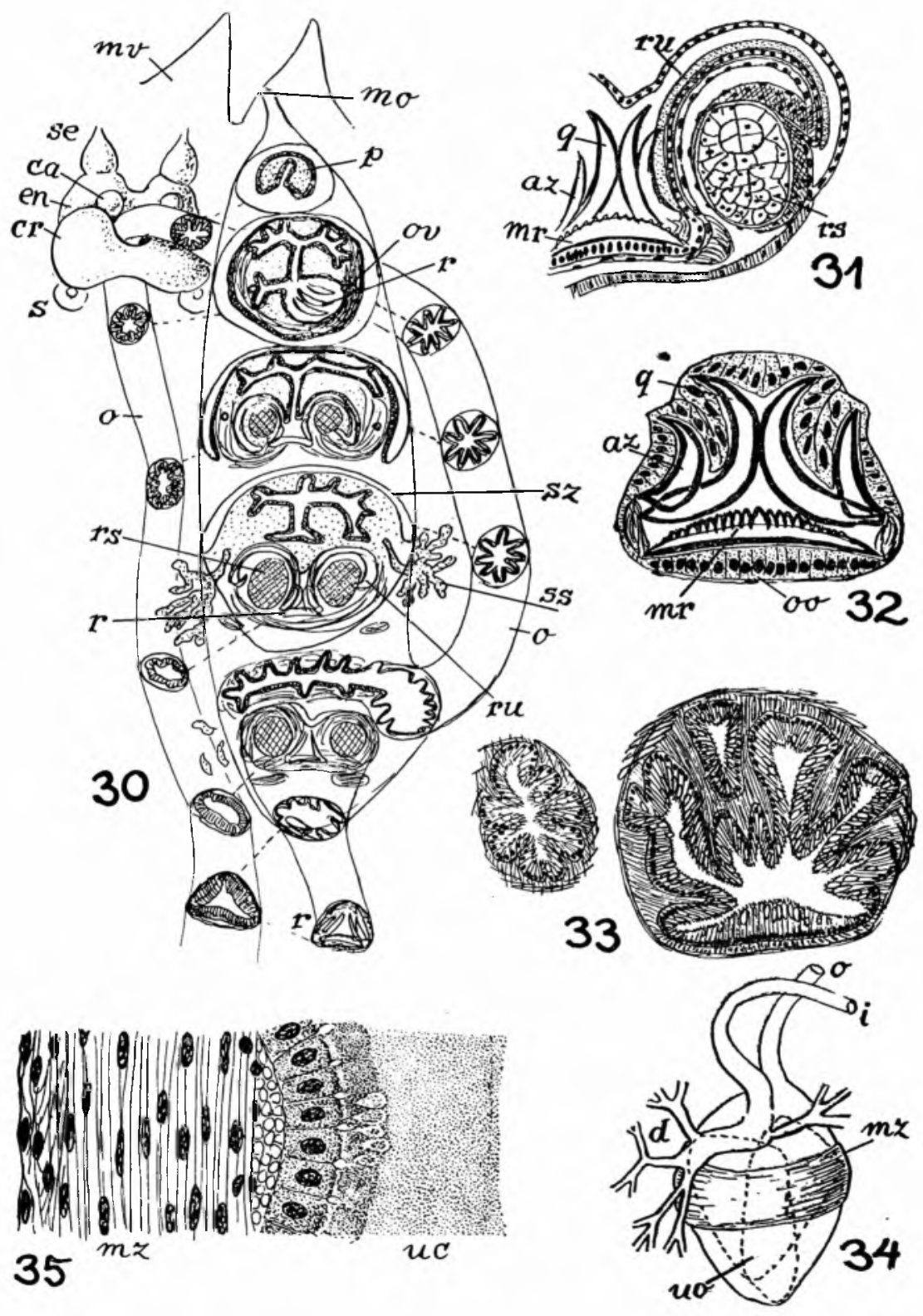




\section{PLATE 7}

Fig. 36 - Olivella, opened stomach.

Fig. 37 -- Olivella, section of pyloric region.

Fig. 38 - Oliva, alimentary tract.

Fig. 39 - Oliva, stomach distended by food.

Fig. 40 - Lintricula, anterior part of alimentary tract. 
E. \& E. MARCUS - OLIVIDAE - PLATE 7

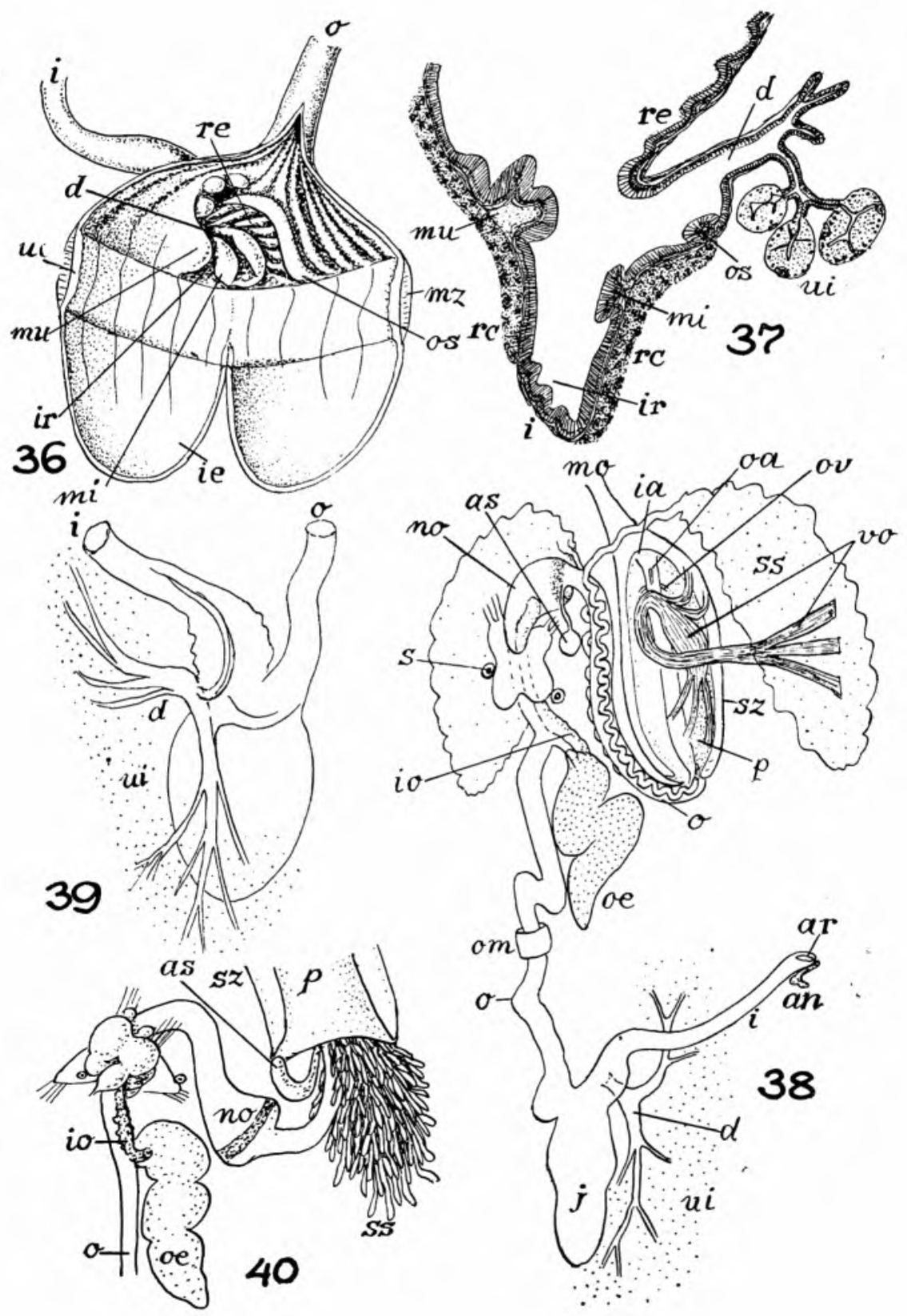




\section{PLATE 8}

Fig. 41 - Oliva, stomach opened by median dorsal cut.

Fig. 42 - Olivella, male organs in situ.

Fig. 43 - Olivella, transverse section of outer part of penis.

Fig. 44 - Olivella, diagram of female organs.

Fig. 45 - Olivella, section of internal vesicle. 
E. \& E. MARCUS - OLIVIDAE - PLATE 8

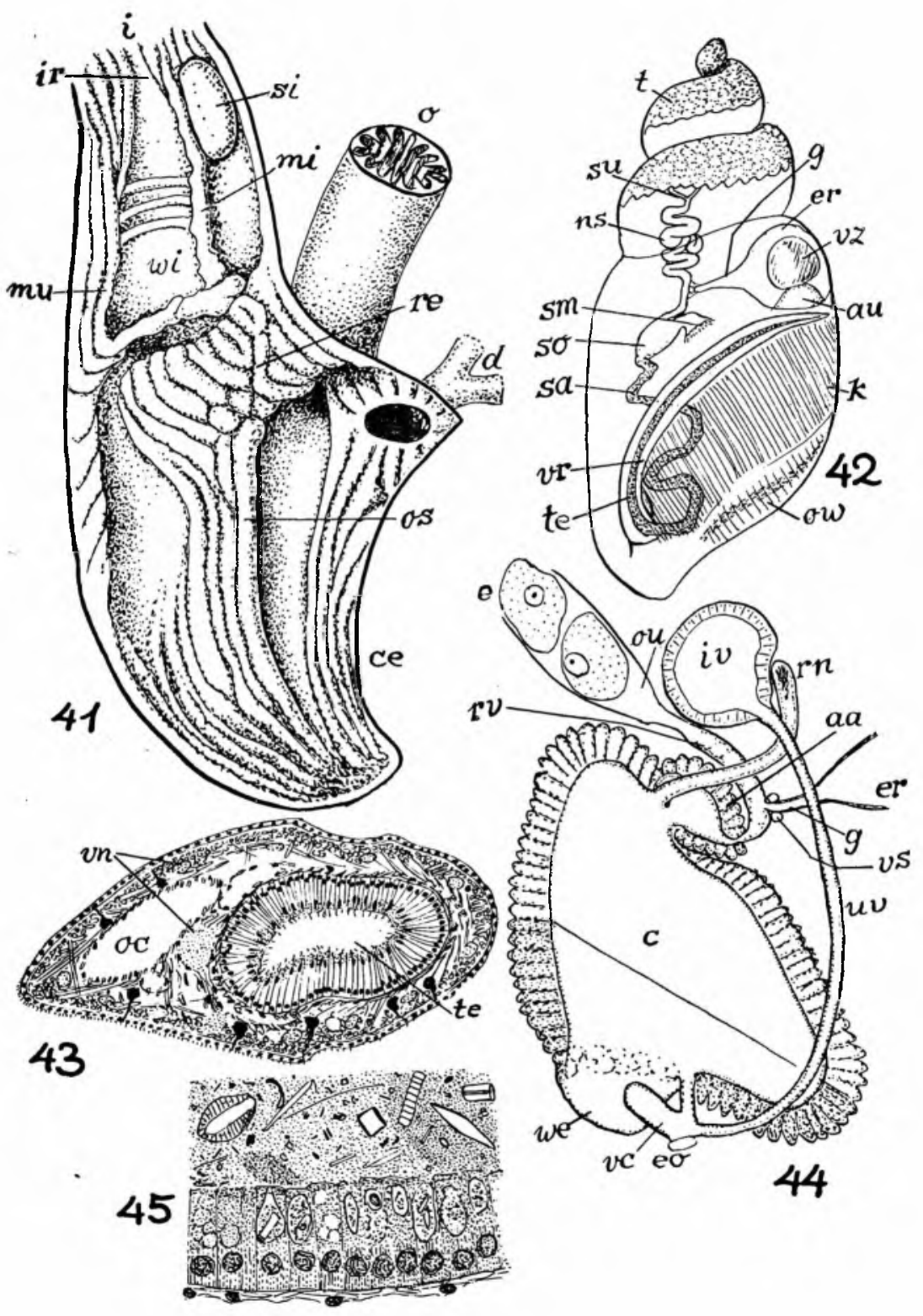




\section{PLATE 9}

Fig. 46 - Olivella, section of capsule gland.

Fig. 47 Oliva, male organs in situ.

Fig. 48 - Oliva, diagram of female organs.

Fig. 49 - Oliva, transverse section of female organs.

Fig. 50 - Olivancillaria, section of ingesting gland. 
E. \& E. MARCUS - OLIVIDAE - PLATE 9

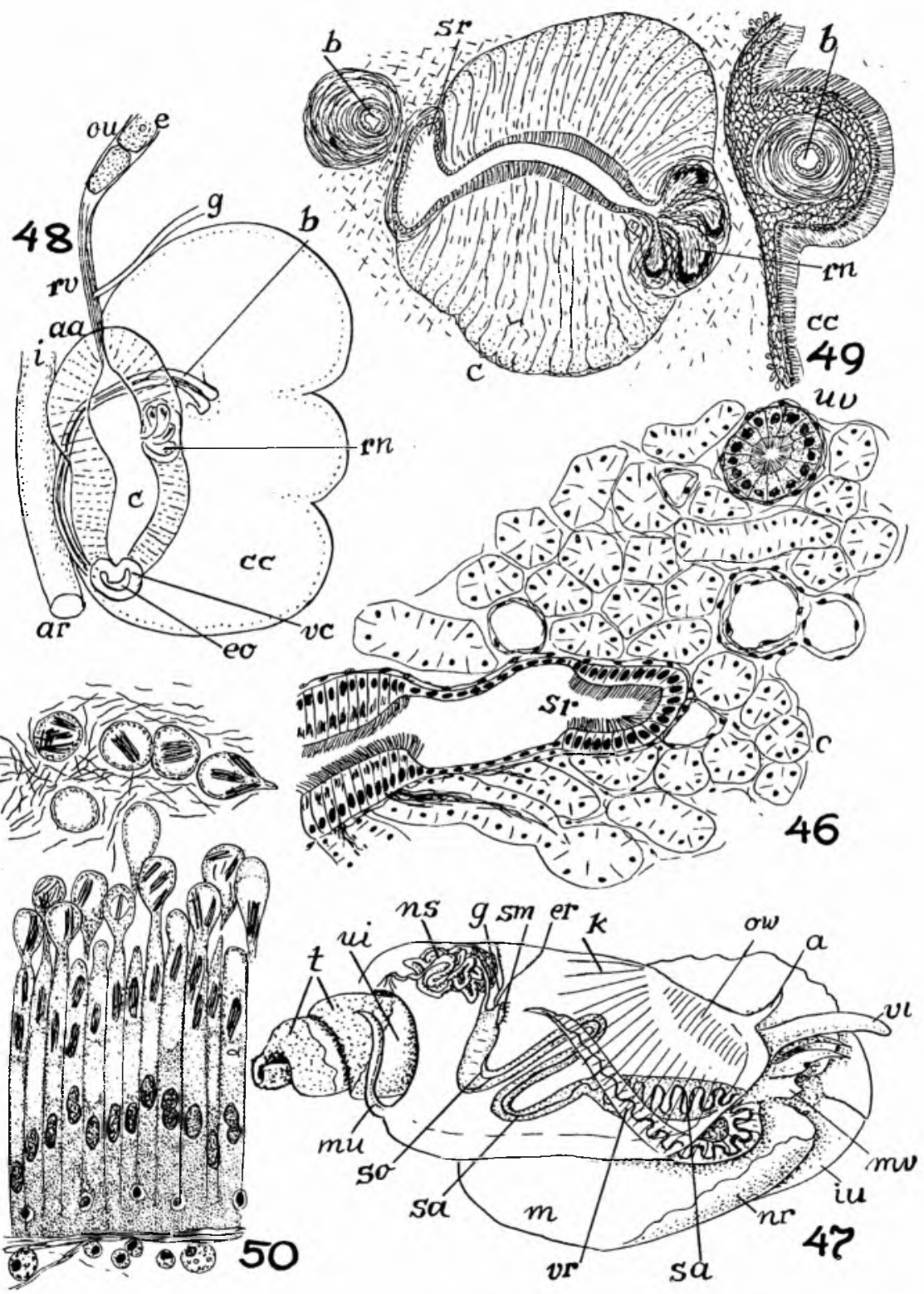




\section{PLATE 10}

Fig. 51 - Lintricula, male organs in situ.

Fig. 52 - Lintricula, transverse section of base of penis.

Fig. 53 - Lintricula, transverse section of penis.

Fig. 54 - Lintricula, diagram of female organs.

Fig. 55 - Lintricula, section of ingesting gland. 
E. \& E. MARCUS - OLIVIDAE - PLATE 10
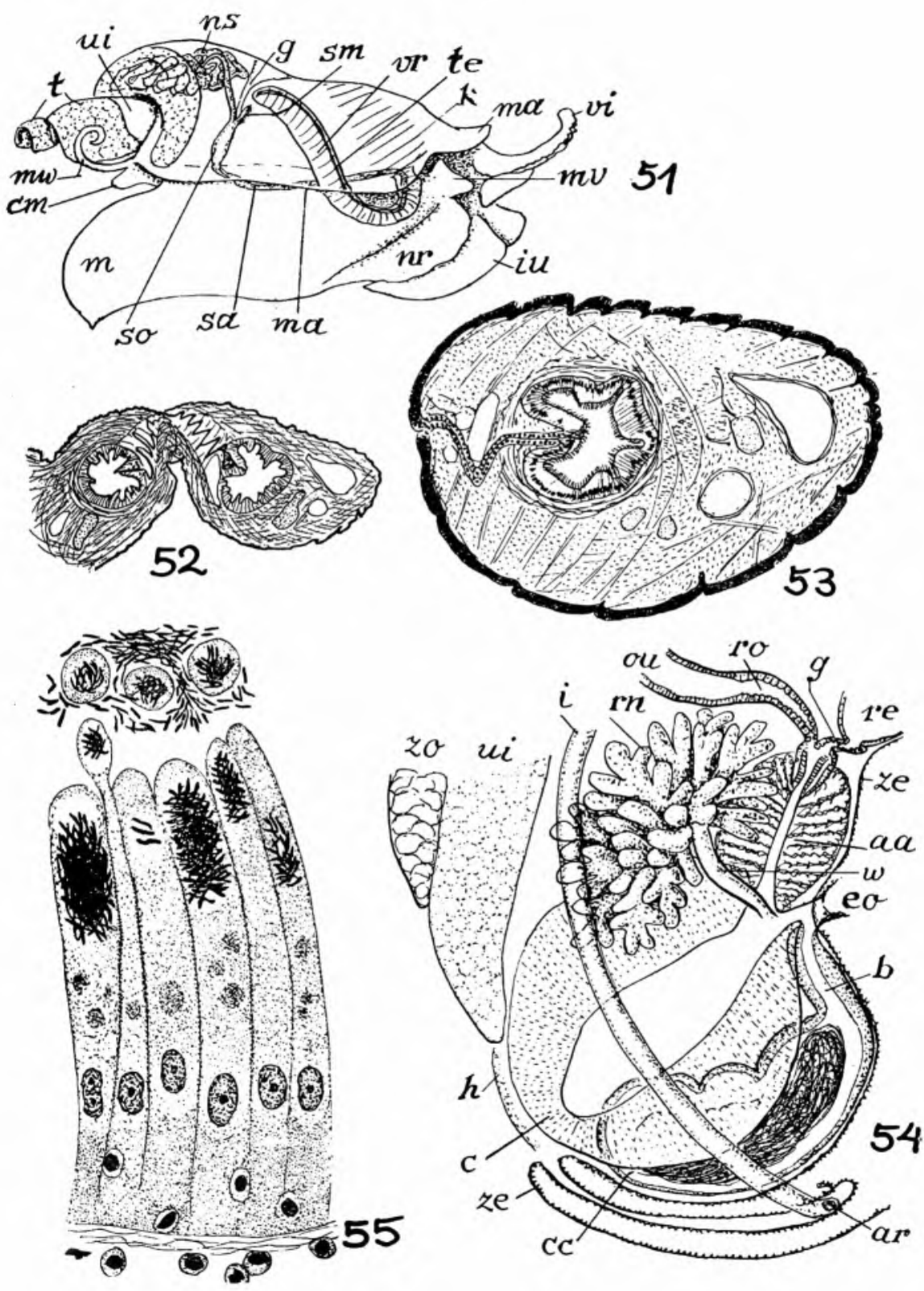


\section{PLATE 11}

Fig. 56 -- Olivella, combined transverse section of renal organ. Fig. 57 Lintricula, villosity of kidney of young snail.

Fig. 58 -- Lintricula, folded part of kidney of same.

Fig. 59 - Lintricula, epithelium of folded part of same.

Fig. 60 - Lintricula, nephridial gland of same; to same scale as Fig. 57.

Fig. 61 - Lintricula, renal organ opened at anterior border.

Fig. 62 - Olivancillaria, merocrine secretion in renal epithelium of folded part. 
E. \& E. MARCUS - OLIVIDAE - PLATE 11

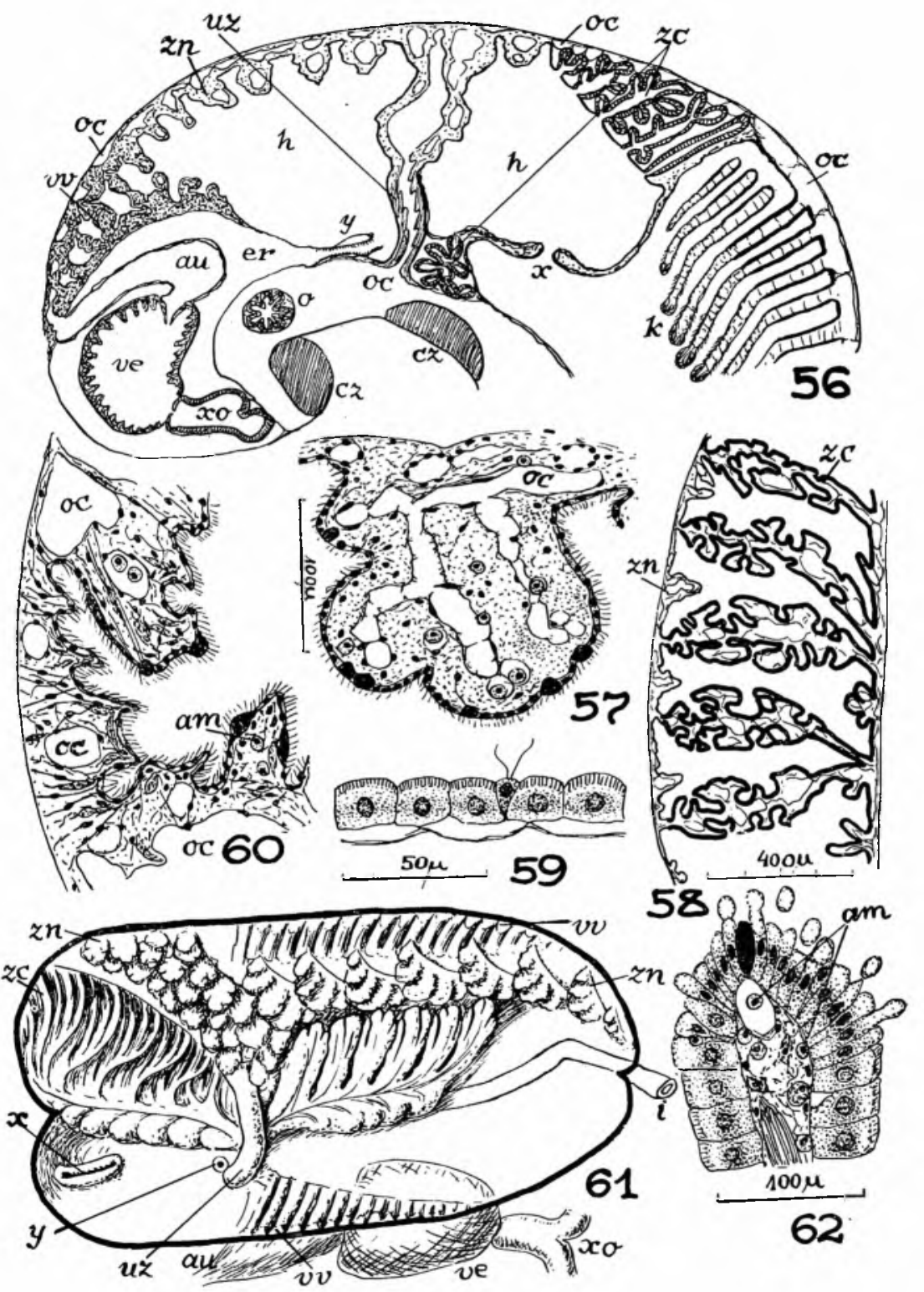


